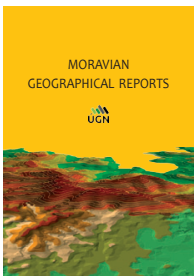

\title{
The role of administrative borders in determining regional identity: The case of Podlasie, Poland
}

\author{
Michał KONOPSKI a *
}

\begin{abstract}
The borders of voivodships in Poland today are not consistent with those of historical regions. The current administrative division is largely based upon imposed boundaries, dividing initial regions. This research topic arises from the dichotomy between the toponymy applied to voivodships because of the administrative reform of 1999 - and the names of historical regions. Implementing such a toponomy, although detached from historical and cultural contexts, has contributed to establishing attachments with current administrative regions, which surpasses identification with historical units. This paper presents the results of empirical research employing a questionnaire survey of the inhabitants of 71 communes (LAU 2 units) in north-eastern Poland. The main objective was to examine the impact of recent administrative reform on territorial identity, with particular emphasis placed on the region of Podlasie. The surveyed communities are to the highest extent attached to national and local levels than to the region, which was only ranked third in the hierarchy of identification with a given area. The regional identity of the population living in north-east Poland is related primarily to the contemporary administrative borders. There are, however, explicit differences in perceptions of the region of Podlasie depending upon respondents' place of residence, which is an indication that relict borders persist in the residents' social consciousness.
\end{abstract}

Keywords: administrative borders, historical region, territorial identity, place attachment, Podlasie, northeastern Poland

Article history: Received 26 February 2020, Accepted 27 November 2020, Published 31 March 2021

\section{Introduction}

Borders, both constituting barriers and those acting as stimulants, have a multifaceted spatial impact: from economic (border trade, international trade exchange: Komornicki, 2010; Powęska, 2011) and social (e.g. education, demography: Palmowski, 2007; Pászto et al., 2019), to an intangible aspect manifesting itself in forming, within a given territory, a sense of community and belonging to a elimited area. Border changes may modify the strength of attachment to various spatial levels, including regional ones (Weigend, 1950; Erikson, 1974; Huntington, 1998; Rykiel, 2010; Scott, 2018).

In the process of the deinstitutionalisation of "old" regions and institutionalisation of new ones, regional identity may either foster or hinder the mechanism of region-building (Zimmerbauer et al., 2012). Initial territorial identities are often weakened, while new ones are established, bearing different perception of boundaries, values and symbolism. On the other hand, the deinstitutionalisation of regions can also stimulate a hitherto dormant territorial identity of inhabitants, including their attachment to a delimited area and a region's name (Zimmerbauer et al., 2012). Therefore, the impact of administrative reform often results in increasing and/or altering administrative "regiocentrism" (Matykowski, 2017). All the while, the evolution of state and regional borders is a 'natural' phenomenon. Similarly, consciousness of the existence of a common territory associated with a particular area is not a given, once and for all (Rykiel, 1985). Moreover, often borders were established secondary to the spatial development of a given area (subsequent borders: Hartshorne, 1936). They not only divided existing economic systems, but also separated previously formed cultural communities.

The permanence of borders is crucial for the formation of emotional ties with an area once they have been delimited. During the Middle Ages and the First Republic of Poland, as an example, administrative regions were characterised by high border stability (Solarz, 2014). In the case of most

\footnotetext{
${ }^{a}$ Institute of Geography and Spatial Organization, Polish Academy of Sciences, Warsaw, Poland (*corresponding author: M. Konopski, e-mail: konopski@twarda.pan.pl)
} 
voivodships ${ }^{1}$ (provinces), they did not change for centuries until the partitions at the end of the $18^{\text {th }}$ century. Such durability of borders contributed to the formation of a strong regional identity attributed to communities of 'small homelands' (Sobczyński, 1984). Since the time of the partition of the Republic of Poland, state borders and internal administrative divisions of the partitioning powers have shifted numerous times. After World War II, administrative reform in Poland has been carried out on average every 25 years. It is then a relatively short period for a community to develop ties with a given administrative region. At present Poland's society is comprised of at least three generations growing up in different territorial divisions of 17 (19501975), 49 (1975-1998) and 16 voivodships (after 1999).

The essence of the research problem considered here stems from the dichotomy between the names (toponyms) ascribed to voivodships as a result of the administrative reform of 1999, and the names of historical regions (i.e. from the time of the First Republic of Poland). The borders of the new administrative units (see Fig. 1) are characterised by a significant lack of cohesion with the spatial range of the historical regions (Miszczuk, 2003; Zaborowski, 2013). Their toponyms, however, refer to the latter. The borders of current voivodships have been imposed, dividing once coherent regions. On the other hand, there are still relict borders present in general social consciousness, resulting from historical conditions, divisions of former Piast ${ }^{2}$ districts or partitions ${ }^{3}$. These borders are apparent, for example, in the diversity of electoral preferences, settlement structure, demographic conditions, land use, cultural landscape, Polish language regionalisms and traditions, etc. (Sadowski, 1997; Barwiński, 2004, 2012; Bański et al., 2012; Ferenc, 2016; Mazur, 2016).

The main aim of this article is to analyse the impact of the last administrative reform (from January 1, 1999) on the regional identity of the inhabitants of north-eastern Poland. Particular emphasis has been placed upon attachment to and perception of Podlasie. A social survey was employed to identify the intensity of respondents' attachment to different tiers and categories of spatial division, taking into account current and historical boundaries of administrative and physico-geographical units, and to reveal spatial perceptions of Podlasie. The research results are anticipated to determine the strength of regional identity in relation to other spatial levels. The survey that was conducted will also serve to ascertain whether Podlasie operates in respondents' consciousness as an historical entity (delimited by relict borders) - or merely - an administrative region (i.e. Podlaskie Voivodship) established as a result of the reform in 1999.

\section{Theoretical background}

\subsection{Attachment to territory}

Individualised relations with a given territory are presented by both its inhabitants and its researchers. Attitudes towards place are shaped by one's experience and

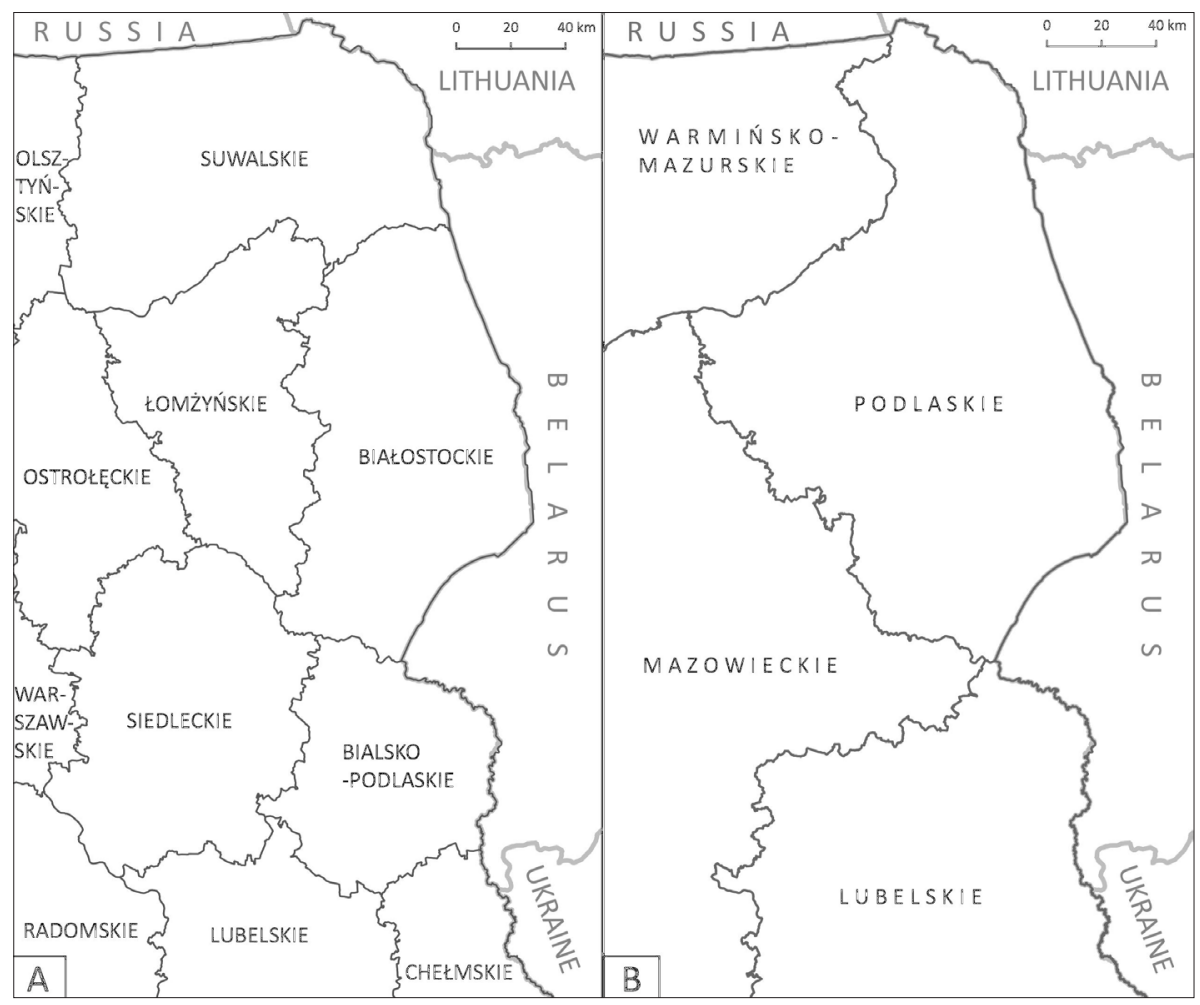

Fig. 1: The voivodships of north-eastern Poland: 1975-1998 (A) and since January 1, 1999 (B) Source: author's composition

\footnotetext{
${ }^{1}$ Voivodship (in Polish: województwo) is an administrative region of the highest rank in Poland (NUTS2 region). It corresponds to Italian provinces (province d'Italia) or kraje in the Czech Republic.

2 The Piast dynasty was the first historical ruling dynasty of Poland. The first documented Polish monarch was Duke Mieszko I (c. 930-992). The Piasts' royal rule in Poland ended in 1370 with the death of King Casimir III the Great (Kaziemierz III Wielki).

${ }^{3}$ In 1795 , the third and the last of the three $18^{\text {th }}$-century partitions of Poland, ended the existence of the Polish-Lithuanian Commonwealth. The partitions were conducted by Habsburg Austria, the Kingdom of Prussia and the Russian Empire, which divided up the Commonwealth lands among themselves progressively in the process of territorial seizures and annexation. The sovereign state of Poland was re-established in 1918.
} 
background (Tuan, 1974). A diversified approach towards this issue is evidenced by the variety of terms employed by researchers, such as: territorial identity, territorial consciousness, territorial awareness, place identity, place attachment, sense of place and others (Korpela, 1989; Low, 1992; Paasi, 2003; Pretty et al., 2003; Pollice, 2003). This subject matter has been undertaken by researchers from environmental psychology, sociology, human geography, cultural anthropology and other social sciences.

According to Chojnicki (1996), regional consciousness as a state of social consciousness determining regional identity - is an inherent element in the spatial and material formation of a region. Such consciousness is constituted by the character and the region's spatial structure, as well as its values and symbolism. An important dimension of a community's self-determination along with the spatial and functional representation of a region, comprises territorial defining in a formal or informal manner (Whebell, 1973). Such process takes place, among others, by naming the region using endoethnonyms - names by which the community determines its territory of residence, or exoethnonyms terms used by outsiders. Relations between perceiving the region from the "inside" and "outside" have been present in scientific discourse for some time. Paasi (1991) stated that the institutionalisation of regions - the process through which regions come into existence as social, political and economic actors - is composed of both the "identity of a region" (created by outsiders) and "regional identity" (the collective identity of a region's population).

Physical places acquire meaning through personal and group memories, religious and national symbols, as well as by multi-sensorial feelings experienced while being-in-theplace (Patterson, Williams, 2005). In this regard, collective memory is a key factor supporting social identity. It acts as a "material" for the awareness of having a shared past. Collective memory is responsible for transmitting cultural values, including language, groundbreaking events, customs, etc. (Malicki, 2010). Identity built on collective memory is strongly grounded in the past and has greater capacity to outlast territorial changes such as creating a new state or regional borders. This was evidenced by a comparative study of two regions in the Czech Republic by Šerý (2014). The socio-historical development of a region with an uninterrupted continuity results in a greater attachment of residents to the region. Today, regional collective memory also resists changing administrative divisions. Historical and relict borders delineate informal territories, distinguished by their specific cultural landscape (Zarycki, 2018).

Regional identity is a type of spatial identity at a certain scale, often referred to as meso-level. Scale is important in differentiating regional identity from place identity ${ }^{4}$. Even though, in some cases, place identity is employed as a general term for various levels of scale, it is commonly associated with directly perceived space (Pohl, 2004). Research on territorial identity conducted by the Polish scientific community concerning its regional dimension is extensive (Rykiel, 1985; Matykowski, 1996; Szyfer, 1996; PrawelskaSkrzypek, 1996; Schmidt, 1997; Łukowski, 2002; Barwiński, 2004; Rak, 2013; Dziekanowska, 2015; Nowak, 2018). In these studies, a relatively low identification with the regional level in relation to the state or local tiers was often demonstrated. Poland's historical determinants of the $19^{\text {th }}$ and early $20^{\text {th }}$ century did not favour establishing a sense of regional belonging (Matykowski, 2017). As evidenced by Bialasiewicz (2003), however, Poland currently encounters a revival of sentiments related to historical regions - such as Galicja, a part of the Austro-Hungarian Empire or Upper Silesia, where in the 1990s the Movement for Silesian Autonomy (Ruch Autonomii Śląska) was established (Bialasiewicz, 2002). There has also been a renaissance of regionalism in Kashubia, a region located on the Baltic Sea coast (Mazurek, 2010).

Research pertaining to people's attachment to a region is difficult as the concept of region itself is burdened by an ambiguity of spatial range - being one of the basic categories in the social sciences but at the same time a vaguely defined term, both in conceptual and semantic aspects (Paasi, 2002). As opposed to most other territorial tiers, region is a highly mobile, plural and geographically ambiguous notion rather than a stable ontological category (Antonsich, 2010). The majority of regions have fuzzy borders and diffused identity and thus this place scale is not the most common study object (Lewicka, 2011). Tuan (1975) claims that a direct phenomenological experience converts "abstract spaces" into "meaningful places" and for this reason region "is far too big to be directly experienced by most of its people. Region is primarily a construct of thought" (p. 158). Importantly, current regions are often units that have emerged from the desks of planners or politicians (Paasi, 2003). Comparative international research conducted in this respect by Laczko (2005) has shown that regions are perceived as less important objects of emotional attachment in comparison to other territorial tiers. On the other hand, there are certain regions with strong identification, characterised by a desire for independence (Basque country, Catalonia) or autonomy (Silesia in Poland) (Lewicka, 2011).

\subsection{Administrative divisions versus historical regions in Poland}

Building regional identity, as well as the spatial and material formation of a region, is closely associated with delimitation of its borders (Matykowski, 2017). This can be based on subjective assumptions and criteria or may result from a spatial unit that is unarguably separated from the environment (Miszczuk, 2003). Administrative regionalisation is therefore an institutionalisation of a natural or artificial (anthropogenic) region. As evidenced by Antonsich (2010), however, an administrative region does not possess a monopoly on the semantics of the spatial unit that it claims to embody, not only in administrative, political or economic terms, but also in identity terms (p. 269).

Territorial division has been regarded as one of the determinants comprising the "administrative power" of the state (Giddens, 1985). Administrative regionalisation is affected by a number of conditions, which include geopolitical location, environmental factors, level of economic development, demographic potential, ethnic and cultural diversity, etc., largely depending on the country under purview. Therefore, there is no universal model for territorial division of the state (Pezzini, 2000). In the (late $16^{\text {th }}$ to late $18^{\text {th }}$ century) times of the First Republic of Poland (Polish-Lithuanian Commonwealth), administrative

\footnotetext{
${ }^{4}$ As stated earlier, place identity, place attachment and territorial identity are often used interchangeably in the literature. According to Lewicka (2011), however, place attachment develops relatively quickly, while place identity requires time. In this sense, place, as opposed to space, is considered "meaningful location" (Tuan, 1974).
} 
division was mainly determined by the Catholic Church structures and borders of historical (Piast) regions. In contrast, the period of the People's Republic of Poland (in essence from the end of World War II through to 1989) saw primarily economic concepts of administrative division put into place (Miszczuk, 2003). The era of Poland's post-1989 political transformation thus informed scientists to attend to the need for a new territorial division, underpinned by rational and objective assumptions (Kołodziejski, 1991; Szczepkowski, 1991).

Regional identity, as a relevant aspect of historical conditioning, was considered an important criterion for the new administrative division. Schattkowsky (1996), Geiss (1996) and Otremba (1997) stressed the importance of historical conditioning in the transformation of Central and Eastern European countries. Poland's latest administrative reform did not take much account of historical conditions, however, as the new voivodships were delimited. A lack of consistency can be observed in the nomenclature of these newly established units, with a mixture of names deriving from historical regions and others referring to capital cities. In no way are the borders of contemporary voivodships consistent with those of historical Polish regions (Miszczuk, 2003; Zaborowski, 2013; Nowak, 2018.). The current administrative division of the country, which in its assumptions adapts Poland to the principles of regionalisation implemented in the European Union, was criticised even before it became applicable in 1999. Shortly after the reform, Bialasiewicz (2002) recognised the disjunction between the administrative Upper Silesia (Śląskie Voivodship) and Upper Silesia, as constituted in socio-spatial consciousness. The recent territorial division deviates from all of the concepts presented by the scientific community (Miszczuk, 2003), which indicates the need to introduce a number of corrections (cf. Zaborowski, 2013).

\section{Study area}

The research area covers north-eastern Poland. For many centuries it has been the territory where various cultures and political influences clashed. The region of Podlasie encompasses the larger part of the area being examined. Its "cradle" is unanimously considered by researchers to be the middle Bug river basin (Jabłonowski, 1910; Gloger, 1918; Wiśniewski, 1977; Piskozub, 1987). Its historical past contributed to its national, religious, linguistic and, as an outcome, cultural diversity. Currently, it is one of the most diverse regions of Poland in this respect (Barwiński, 2004).

The administrative region called Podlaskie Voivodship ${ }^{5}$ historically existed in two different border variants. The current province is its subsequent, third modification. The first voivodship of Podlasie (also referred to in this paper as historical Podlasie) was established in 1513, and from 1566 to 1795 , thus for over 200 years, it had unchanged borders (see Fig. 2). The third partition of Poland in 1795 changed its initial territorial unity. The Bug River, once a regional development axis, has since become a state border and today an administrative one. During the partitions, the second Podlaskie Voivodship was delimited ${ }^{6}$, as a fragment of historical Podlasie region south of the Bug River and sections of adjacent voivodships from the time of the First Polish Republic (Michaluk, 2013).

In 1999, as an outcome of the administrative reform, Podlaskie Voivodship found itself with changed borders among the newly established regions. Despite its toponym, when delimiting this administrative unit, only the northern part of historical Podlasie was taken into account. Other fragments located south of the Bug river - are now part of Mazowieckie and Lubelskie Voivodships (Fig. 2). The new Podlaskie Voivodship, on the other hand, includes areas that historically have never belonged to Podlasie. The current administrative division is debatable at the outset on the basis of analysing the names of towns. For instance, Sokołów Podlaski is located in the Mazowieckie Voivodship, while Biała Podlaska or Międzyrzec Podlaski are in the Lubelskie Voivodship.

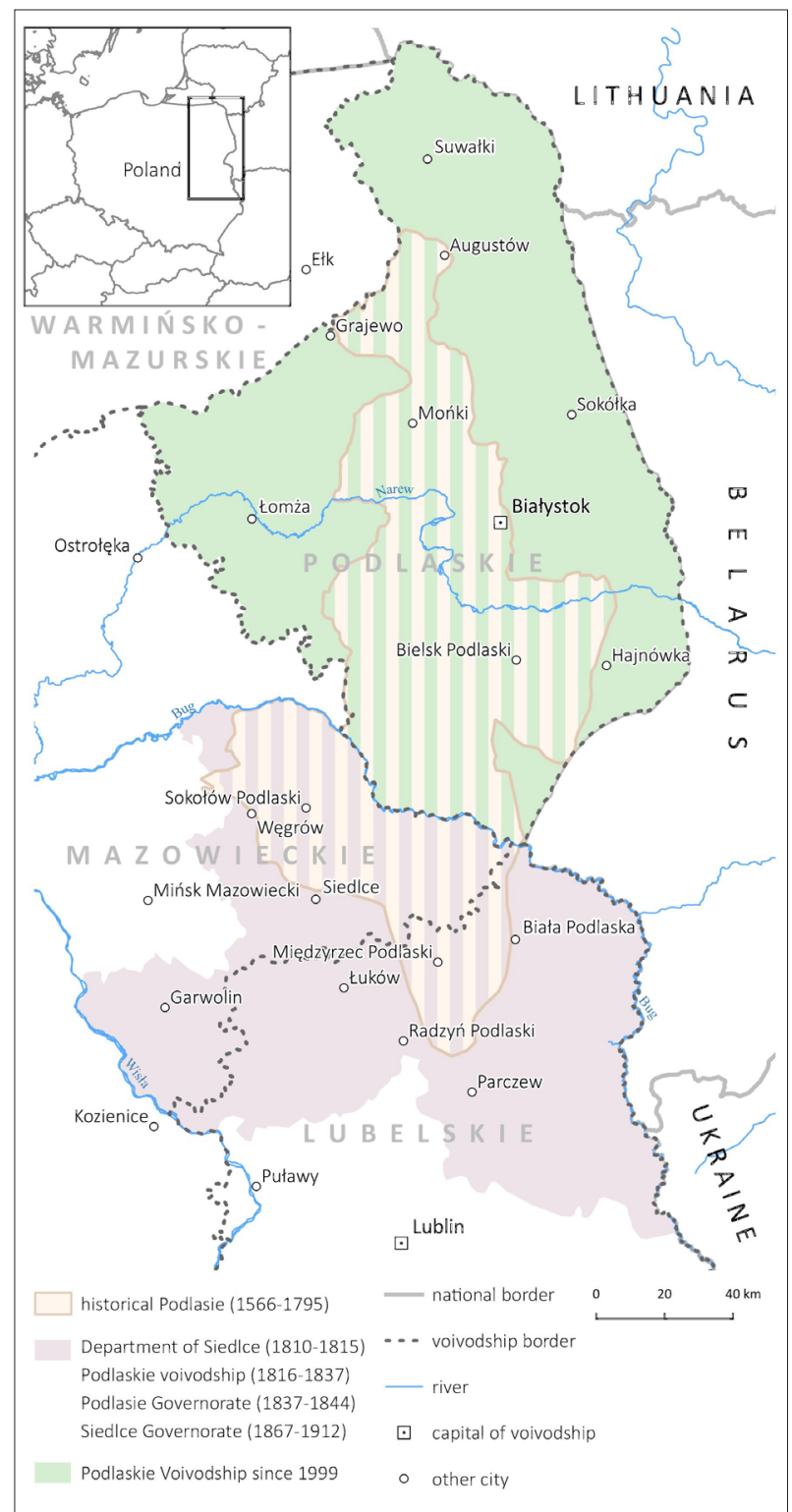

Fig. 2: Borders of historical and contemporary administrative units in the research area

Source: author's elaboration based on Gloger, 1918; Barwiński, 2004; Żóttowska, 2011

${ }^{5}$ Podlaskie is an adjectival form of Podlasie in the Polish language. Similarly, other names of voivodships were constructed as an aftermath of administrative reform in Poland: e.g. Mazowieckie Voivodship (adjective of Mazovia, a historical region in central Poland), or Wielkopolskie Voivodship (adjective of Wielkopolska, a historical region in western Poland).

${ }^{6}$ During the partitions the following administrative regions were established, covering the same area: Department of Siedlce (1810-1815); Podlaskie Voivodship (1816-1837); Governorate of Podlasie (1837-1844); Governorate of Siedlce (1867-1912) 
The new image of Podlasie, identified with current Podlaskie Voivodship, has been consolidated in public discourse since 1999. The term Podlasie has become synonymous with the Podlaskie Voivodship in everyday language and the media. Such an approach has also been disseminated by the scientific community (Bałtromiuk, 2003; Bocian, 2003a, 2003b, 2004, 2005, 2008, 2016; CzemielGrzybowska, 2006; Proniewski and Niedźwiecki, 2003; Plawgo and Sadowska-Snarska, 2004; Hryniewicz and Potrykowska, 2017). Furthermore, the terms Podlasie and Podlaskie Voivodship are commonly used as synonyms also by the scientific community of Białystok (as the capital city of the new voivodship and located in historical Podlasie). Theoretically, researchers from this academic centre should present a higher consciousness of their region of residence than the general public. This may result, however, not so much from ignorance, but purely the convenience of authors willingly using these terms as synonyms. By deepening research topics of the current Podlaskie Voivodship, scientists are attempting to avoid over-repeating this term. This is due to the pursuit of a 'correct language' style, which requires avoiding repetition in neighbouring sentences. Podlasie has thus become one of the synonyms for the term Podlaskie Voivodship, next to terms such as region or research area.

In brief, the synonymous use of administrative and historical toponyms has greatly contributed to establishing a specific "identity of the region", attributed to territory enclosed by the borders of the Podlaskie Voivodship. This has happened despite the lack of cultural or historical contexts.

\section{Research method}

The current research project has employed social surveys conducted in 71 communes (LAU 2 units) of the Podlaskie, Mazowieckie, Lubelskie and Warmińsko-Mazurskie Voivodships. The main criterion for the selection of communes was their location (sample design criterion), in relation to:

1. Borders of the Podlaskie Voivodship from the time of the First Polish Republic (1569-1795), the so-called historical Podlasie (30 communes met this criterion);

2. Shared borders of the Department of Siedlce (1810 1815), Podlaskie Voivodship (1816-1837), Governorate of Podlasie (1837-1844) and Siedlce (1867-1912) (20 communes);

3. Borders of the voivodships of north-eastern Poland according to the administrative division of 1975-1998 (within which a researched community potentially identifies with Podlasie) (42 communes); and

4. Borders of the contemporary Podlaskie Voivodship, established in 1999 (26 communes).

Questionnaire surveys were conducted in communes adjacent to the indicated borders of administrative units (see Fig. 3). Pairs of communes on the inside and outside of a given border were selected, assuming their similar number on both sides. An additional criterion was the inclusion of several communes not neighbouring voivodship borders. The purpose of this approach was to analyse the territorial identity of communities living away from the boundaries of administrative regions. The research covered only rural and urban-rural communes assuming the highest share of autochthons with well-established place attachment and rootedness.
Questionnaires were posted to primary and/or junior high schools located in the main towns of a commune. By means of the pupils, surveys were addressed to adult respondents (parents, grandparents and other household members). Such a research method was previously implemented in numerous studies in Poland (e.g. Komornicki et al., 2013; Janc et al., 2019). Pilot studies allowed the selection of the optimal variant for conducting final surveys and the calibration of the research tool. In the period from February 17, 2017 to January 10, 2018, 19,540 questionnaires were sent to 73 schools, resulting in 9,537 received from 71 communes. The return rate was almost $49 \%$. One advantage of this method is the possibility to reach a large number of respondents. On the other hand, the research sample is strongly limited to populations with school-age children, which largely determines the age group of respondents to 30 to 49 years. For a more reliable outcome, weighting was applied to the obtained responses from examined communes, proportionally adapted to its actual demographic structure.

The questionnaire employed closed questions involving Likert-type scales $(0$ being the minimum: representing no attachment, and 5 the maximum value: highest attachment).

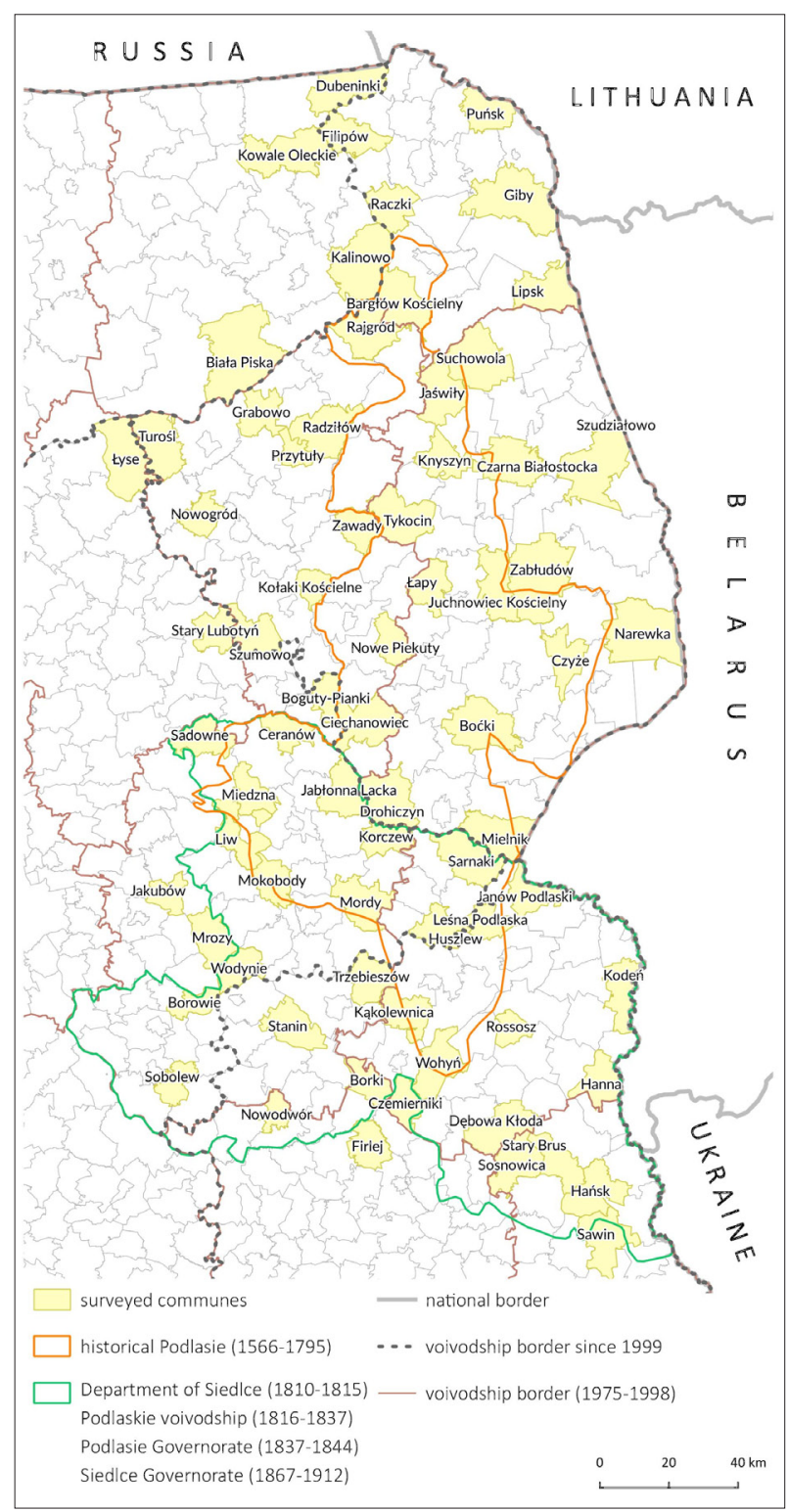

Fig. 3: Surveyed communes in the research area in relation to contemporary and historical borders Source: author's elaboration of field survey locations 
In this way attitudes towards 11 spatial tiers were assessed. These were as follows: Europe, European Union, Poland, Eastern Poland, current voivodship (since 1999), former voivodship (1975-1998), Podlasie, physico-geographical macroregion, district (LAU 1), commune (LAU 2), village/ place of residence. Mean values for attachment to spatial levels were then calculated. Analysis was employed to verify the statistical significance of factors potentially determining attachment towards examined spatial tiers. These included the following respondents' characteristics: gender, fact of being born in surveyed commune (Mann-Whitney U tests), age, education level, time of residence (Student's T-tests), occupation, religion and declared nationality (KruskalWallis tests by ranks).

The remaining questions aimed at analysing attachment at the regional level, with special emphasis placed on Podlasie (along with current and former administrative regions) also involved Likert-type scales. The questions were as follows:

a. Do you live in Podlasie?

b. Would you like to restore the former voivodship from the years 1975-1998?

c. Do you consider that Podlaskie Voivodship and Podlasie cover the same area?

These questions employed the Likert ordinal scale. Respondents were given the following options to select: definitely yes; rather yes; rather no; definitely no; difficult to say. Based on the obtained responses, a quantitative interval scale was developed. The results were interpreted as synthetic mean values expressed as a scale of 0 to $100 \%$, where 0 meant that all respondents answered "definitely no" and $100 \%$ for all respondents answering "definitely yes" to a given question.

In applying cartographic presentation methods, the research aimed at identifying the spatial structure of survey results. The research was conducted at selected points, thus the added cognitive value of cartographic visualisation is the transformation of quantitative data into a continuous spatial model. For this purpose, a series of isopleth maps was constructed (see Figures 6-8, below), which through interpolation and extrapolation show directions and dynamics of value changes in geographic space. This method allows one to capture the spatial variability of questionnaire findings holistically within the entire research area. On the other hand, exact values of results are retained only at the measurement points - the geographical coordinates of a schools' premises.

A dedicated section in the questionnaire served to examine perception of Podlasie in spatial terms among surveyed residents. For this purpose, respondents were asked the following question:

d. Where do you think Podlasie is located? Please outline the borders of Podlasie on a schematic map.

A simplified schematic map (see Fig. 9 below) was included, which only provided state borders and the location of 46 towns (LAU 1 and voivodship capitals of north-eastern Poland) for basic reference purposes. The percentage of towns included within the outlined region are presented employing the method of isolines.

\section{Results and discussion}

The structure of the research sample is definitely dominated by women (70\%). The most represented age group of respondents is $30-39(44 \%)$. The share of the 40
49 age group is also important (38\%), while the remaining categories are less numerous: 50-59 (9\%), 60 and above $(5 \%)$ and $18-20(4 \%)$. It is noteworthy that the majority of respondents for most of their conscious lives have lived under the current administrative division (since 1999). Most of them $(62 \%)$ were born in the commune where the survey was conducted. The others have lived there for 11-20 years (42\%), more than 20 years (33\%), 6-10 years (16\%), $2-5$ (6\%) and less than 2 years $(3 \%)$. The religious structure of respondents is characterised by a considerable domination of Roman Catholics (94\%). The Orthodox Church followers constituted a small share of population (5\%), and only in three of the surveyed communes were in the majority, in the eastern part of the Podlaskie Voivodship (ranging from $54 \%$ to $88 \%$ ). The majority of respondents (91\%) identify themselves exclusively with Polish nationality. The remaining most represented nationalities are Lithuanians (77\% in case of a single commune by the Polish-Lithuanian border), Belarusians (up to $38 \%$ in the Podlaskie Voivodship), and Ukrainians (maximum share of $11 \%$ in Lubelskie Voivodship). Particularly in the eastern communes of the research area, the share of respondents not declaring any national affiliation but describing themselves as "locals" was significant (even more than $1 / 3$ of the responses). The percentage of such respondents is the highest in communes with a predominantly Orthodox population, especially in the two oldest age groups (50-59 and over 60).

The hierarchy of respondents' attachments to spatial levels in the research area (Figure 4) is characterised by a number of regularities.

In general, respondents identify themselves most strongly with the national level (Poland). The average value of such indications was 4.6 (on a scale of $0-5$ ). Such strongest attachment to this tier was expected. Although respondents are of diverse ethnic backgrounds they are rooted in a common history. Particularly strong in this regard are socially constructed symbols of group belonging and group identity, evoking strong emotional reactions (Lewicka, 2011). The Kruskal-Wallis test by ranks, moreover, reported statistical significance between declaring Roman Catholicism and attachment to Poland. The next tier with which respondents strongly identify themselves is the broadly defined local level. It consists of a well-founded attachment to the district (mean value of 4.4) but especially the commune and locality of residence (4.5). Gender and village/place of residence are statistically significant: men tend to exhibit a slightly stronger attachment at this level, perhaps because northeast Poland is characterised by a relatively stable sociohistorical development with an uninterrupted continuity. There has been no large-scale resettlement after World War II as in western Poland.

Numerous respondents' families have lived in the same villages for generations. Considering that a major proportion of respondents are farmers, they are strongly attached to their land as it is part of their patrimony and heritage. It is noteworthy that the local level is identified to a higher extent in the examined communes of peripheral location than those in the vicinity of the voivodship or subregional centres, where population tends to be more mobile. Peripheral communes are more isolated in spatial terms and local communities are characterised by lower mobility. As observed by Kelly and Hosking (2008), those who spend more time in the place feel more attached. This has been demonstrated here by means of a Student's T-test, as there is a statistically significant association between age of respondents and attachment to 


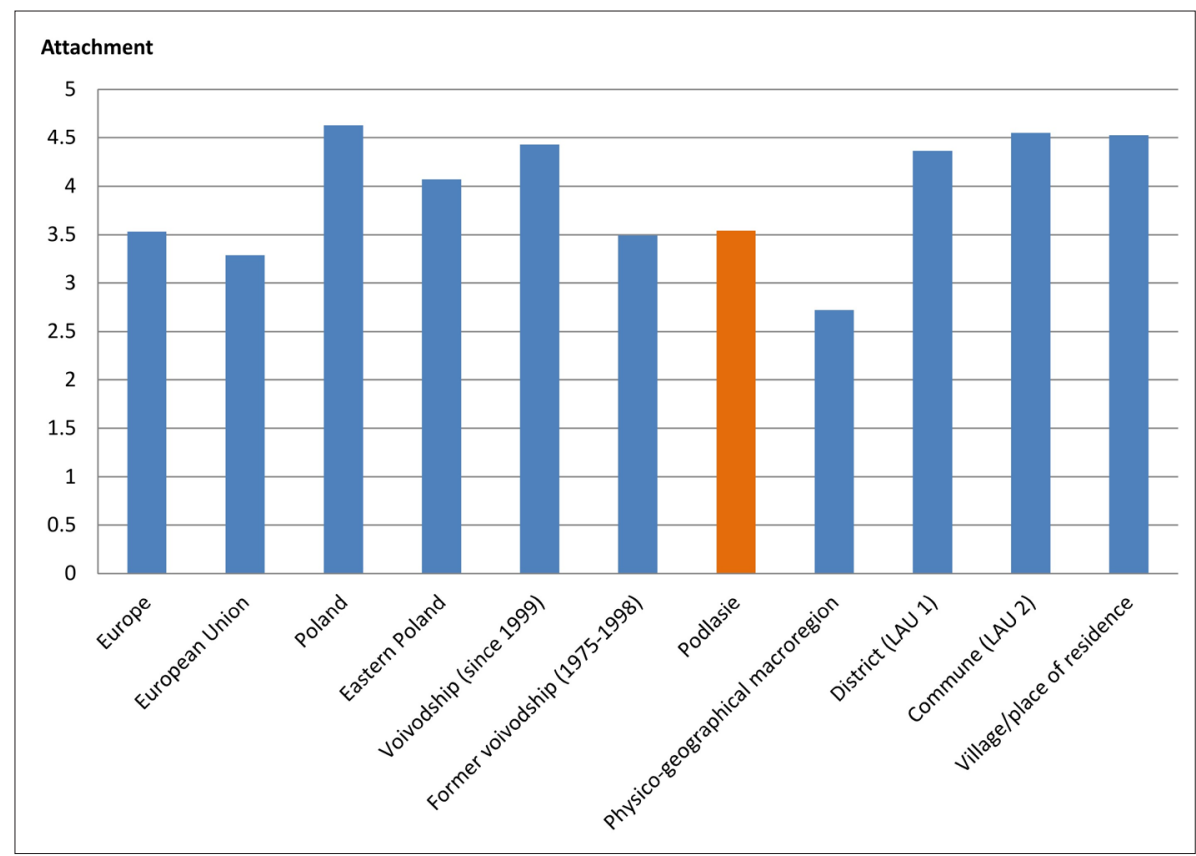

Fig. 4: The hierarchy of respondents' attachment to spatial tiers (mean values) in the research area (0 represents ' $n$ o attachment' and 5 'highest attachment'). Source: author's survey

commune (correlation 0.024) and village/place of residents (correlation 0.039). Furthermore, a Kruskal-Wallis test showed that the unemployed (thus potentially spending more time in place of residence) are more attached to a village/ place of residence than the population as a whole.

The regional level is the third in this hierarchy of attachment. Respondents most evidently identify themselves with the administrative region established in 1999 (average value of 4.4). The name of the contemporary administrative region is identified more strongly by the respondents as compared to historical regions (3.8). Former voivodships (1975-1998) are characterised by a considerably lower level of identification (3.5), except for respondents inhabiting communes in the vicinity of their prior capitals (Biała Podlaska, Łomża, Siedlce, Suwałki: exceeding 4.0). A student's T-test was employed for verifying whether time of residence affects level of attachment to the spatial tiers under examination. It must be emphasised that only respondents not born in the examined communes were taken into account. In this case, statistical significance is demonstrated, showing a slight negative correlation between time of residence and attachment to the voivodship established in 1999. Thus, the longer one lives (especially in the groups 11-20 and more than 20 years of residence) in this administrative region, the weaker the attachment. This could be explained by the fact that older respondents could be attached to a different region in which they were born and/ or a former voivodship (1975-1998). Younger individuals are more rooted in their present administrative region despite a relatively short time of residence.

As observed by Antonsich (2010), regional identity is not always directed to the institutional regional space. A comparative study conducted in Europe showed that inhabitants of Languedoc-Roussillon (southern France) frequently mentioned the South as a crucial identity marker, while respondents of Finland's Pirkanmaa emphasised their belonging to the West. Such identity is constructed out of a social and economic divide and the attributed unevenness of accumulated capital. This seems to be the case of Eastern Poland as being underdeveloped in numerous aspects compared to other parts of the state and voivodship. Survey results confirmed a strong identification of respondents with the informal region of Eastern Poland showing clear spatial dependencies, gradually intensifying towards the eastern state border. In the case of several communes with peripheral and eastern locations, respondents showed a stronger identification with this informal spatial level than with the institutionalised region (voivodship).

As evidenced by statistical analysis, Eastern Orthodox followers are more attached to Eastern Poland. These respondents also showed the greatest proportion of declaring Belarussian alone or together with Polish identity and/or describing themselves as "locals". In turn, an inverse spatial regularity is characterised by respondents' attachment to supra-state levels - Europe and the European Union. Identification of respondents with these areas is clearly increasing from the east to the west. It is also stronger in communes near larger towns than in peripheries. These communities are characterised by populations that are better educated and feature lower shares of employment in agriculture. Furthermore, there has been demonstrated a statistical significance between declaring atheism and greater attachment to supra-state tiers.

The survey results on the degree of attachment to physicogeographical macroregion is the most polarised spatial level, depending upon examined communes. In addition, the Mann-Whitney U test showed that the fact of being born in an examined commune demonstrated statistical significance only in the case of physico-geographical macroregions. Yet, in general this tier is the last one in the hierarchy of attachment. An interesting pattern was observed among respondents living in the South Podlasie Lowland. The lowest identification with this macroregion is characteristic of its inhabitants living in the Mazowieckie Voivodship, outside the historical Podlasie. Respondents from these communes do not feel attached to a macroregion, whose name suggests relation with Podlasie. The macroregion's toponym may arouse their opposition, as they identify much more strongly with Mazovia and Mazowieckie Voivodships. In the case of other communes located in the eastern part of the 
South Podlasie Lowland, which are located in the historical Podlasie, the level of identification with this macroregion is significantly higher. This confirms the high importance of the name assigned to a given area for ultimate perception.

The level of respondents' attachment to the term Podlasie is strongly diversified in spatial terms. Overall, identification with this region obtained an average value of 3.5. It was by far the highest in the communes of the Podlaskie Voivodship, although relatively polarised (ranging from 3.9 to 4.7). In the case of certain communes, respondents showed a comparable level of attachment to Podlasie and the administrative region (Podlaskie Voivodship), but the latter, formalised by voivodship borders, was stronger. Although the borders of the first Podlaskie Voivodship have not existed since 1795 and the Governorate of Siedlce was abolished in 1912, identification of respondents with Podlasie within these historical borders is still relatively high, especially in the former Bialskopodlaskie Voivodship (see Fig. 5).

These observations concern mainly the $60+$ age group of the surveyed population. A student's T-test showed that age determines level of attachment to Podlasie in this case, with a slight positive correlation of 0.027 . Thus, there is a greater attachment to Podlasie among older respondents within relict borders. Kruskal-Wallis tests demonstrated some statistical significance between identification to Podlasie and occupation. Both farmers and individuals involved in agritourism showed greater attachment to this region. The factor of declared religion also determines such territorial identity: Eastern Orthodox followers are more attached to Podlasie than any other confession. Furthermore, as evidenced by statistical analysis, individuals declaring Belarussian nationality tend to be more attached to Podlasie. The vast majority of them are also Orthodox believers. It is thus difficult to identify one decisive factor in this regard. Respondents living in communes that are located within the boundaries of the historical Podlaskie Voivodship identify themselves to a higher extent with Podlasie than, for example, with the former voivodships (1975-1998), but evidently less strongly comparing to administrative regions established in 1999. Attachment to Podlasie among respondents residing in the communes of the former Bialskopodlaskie and Siedleckie Voivodships is much higher than in the surveyed communes of Warmińsko-Mazurskie Voivodship, which are adjacent to the Podlaskie Voivodship. This is possibly an effect of a historical border between these units, characterised by long durability being a barrier for identifying with Podlasie.

The overriding criterion for respondents' attachment to Podlasie is the location of an examined commune within the borders of contemporary Podlaskie Voivodship and even more so within former Białostockie Voivodship (Figs. 2 and 5, and Tab. 1). The Mann-Whitney $U$ test provided statistical significance between communities located in these administrative regions and identification with Podlasie. In these territorial units, the level of attachment to Podlasie was relatively balanced across all age groups surveyed. This may seem striking, considering that it has been only 20 years since the establishment of this administrative region. The historical criterion, i.e. location in the so-called historical Podlasie, is a secondary feature. A number of communes included in the analysis, which historically did not belong to Podlasie and which are currently located in the Podlaskie Voivodship, present a higher level of respondents' identification with this region compared to the ones which historically belonged to Podlasie but are now located in the Lubelskie and Mazowieckie Voivodships (see Fig. 5).

The role of the administrative region in determining regional identity referring to Podlasie appears to be decisive, but it does not show homogenous spatial intensity (Fig. 6).

Historical borders to some extent still manifest a certain strength of influence, modifying the level and traits of place attachment. The previous Poland's administrative division (1975-1998) persists to affect respondents' relation to the analysed region. Respondents living in the

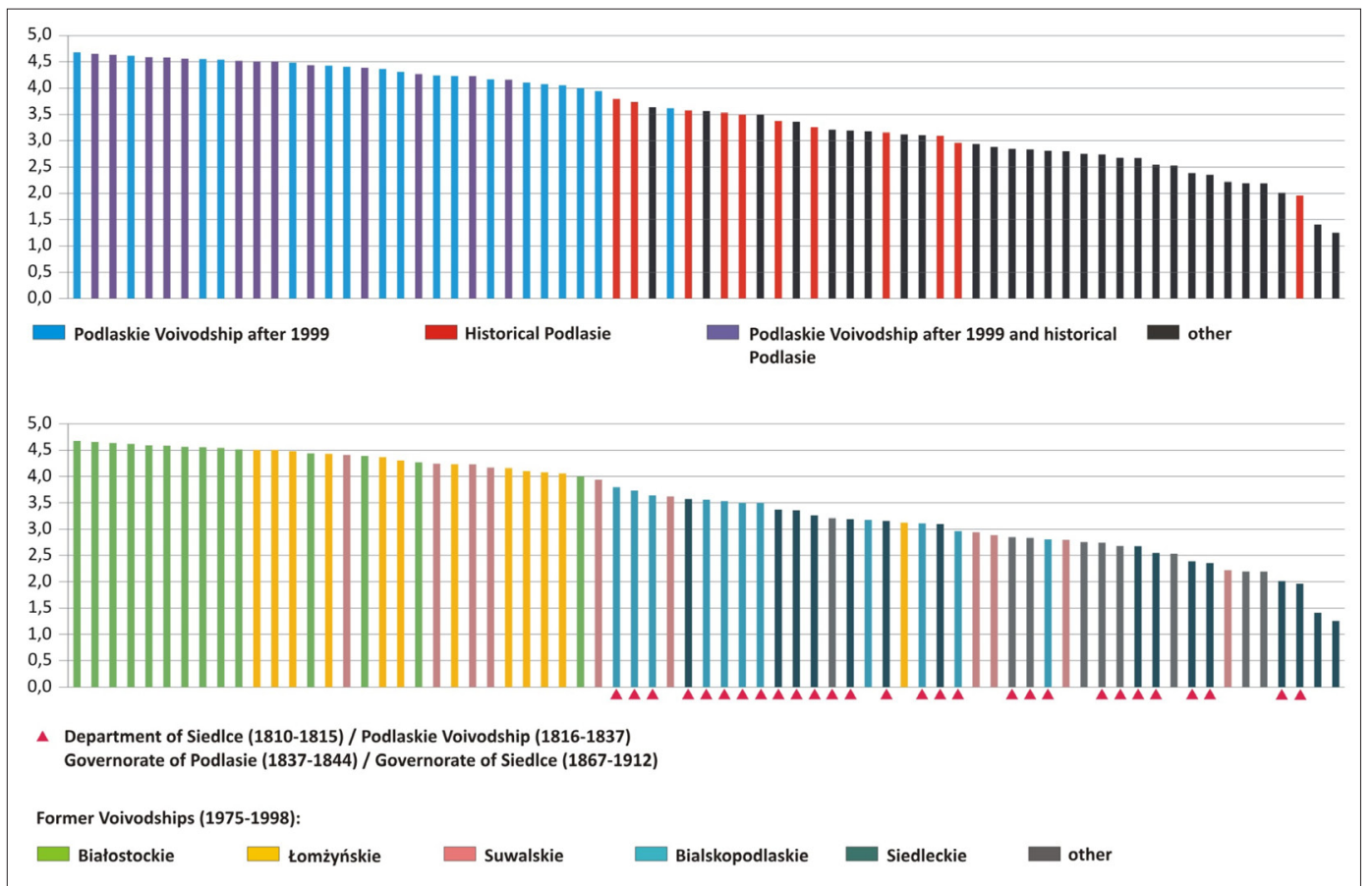

Fig. 5: Level of respondents' identification with Podlasie in the examined communes with respect to contemporary and historical administrative regions (communes were ranked in descending order regarding identification with Podlasie). Source: author's survey 


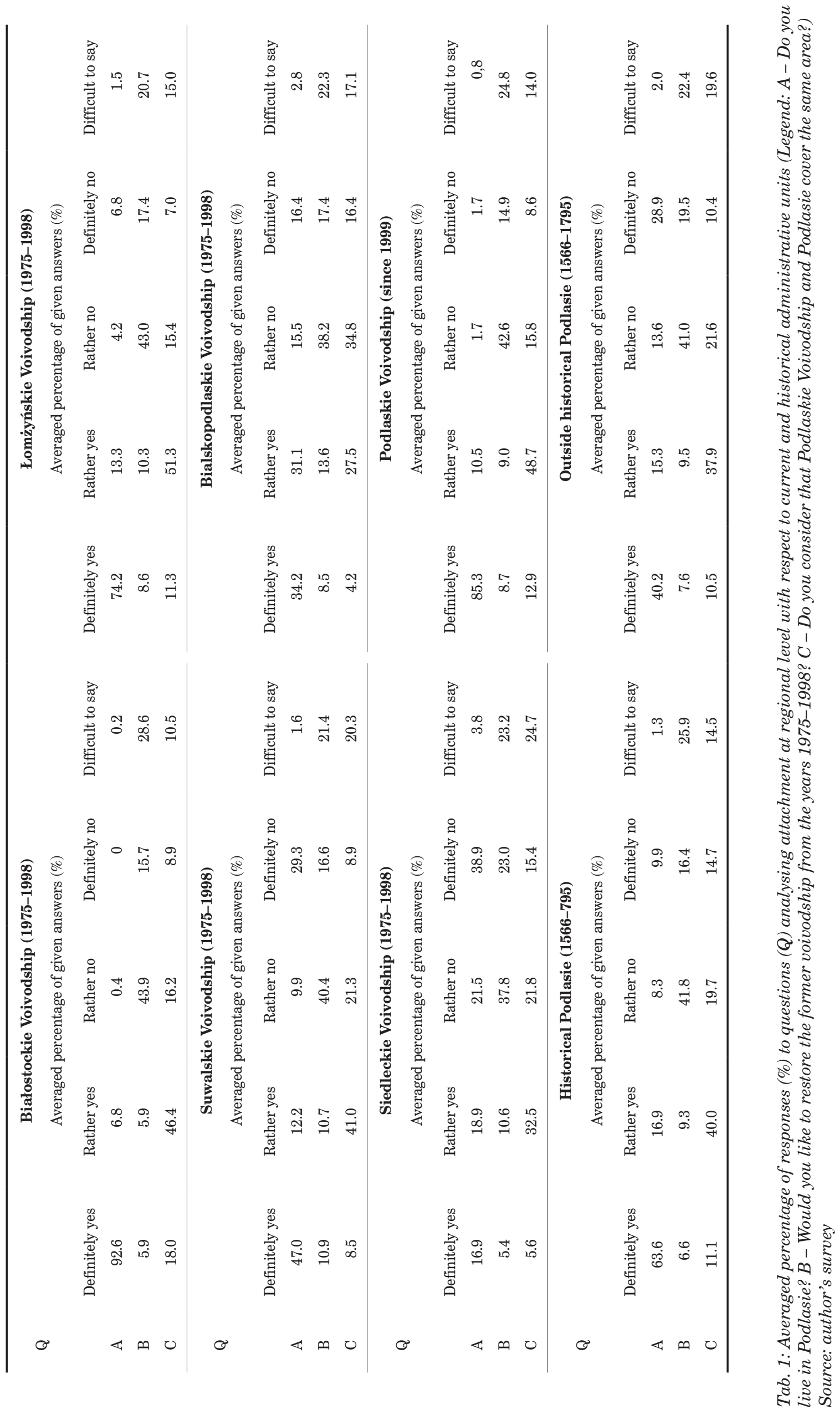




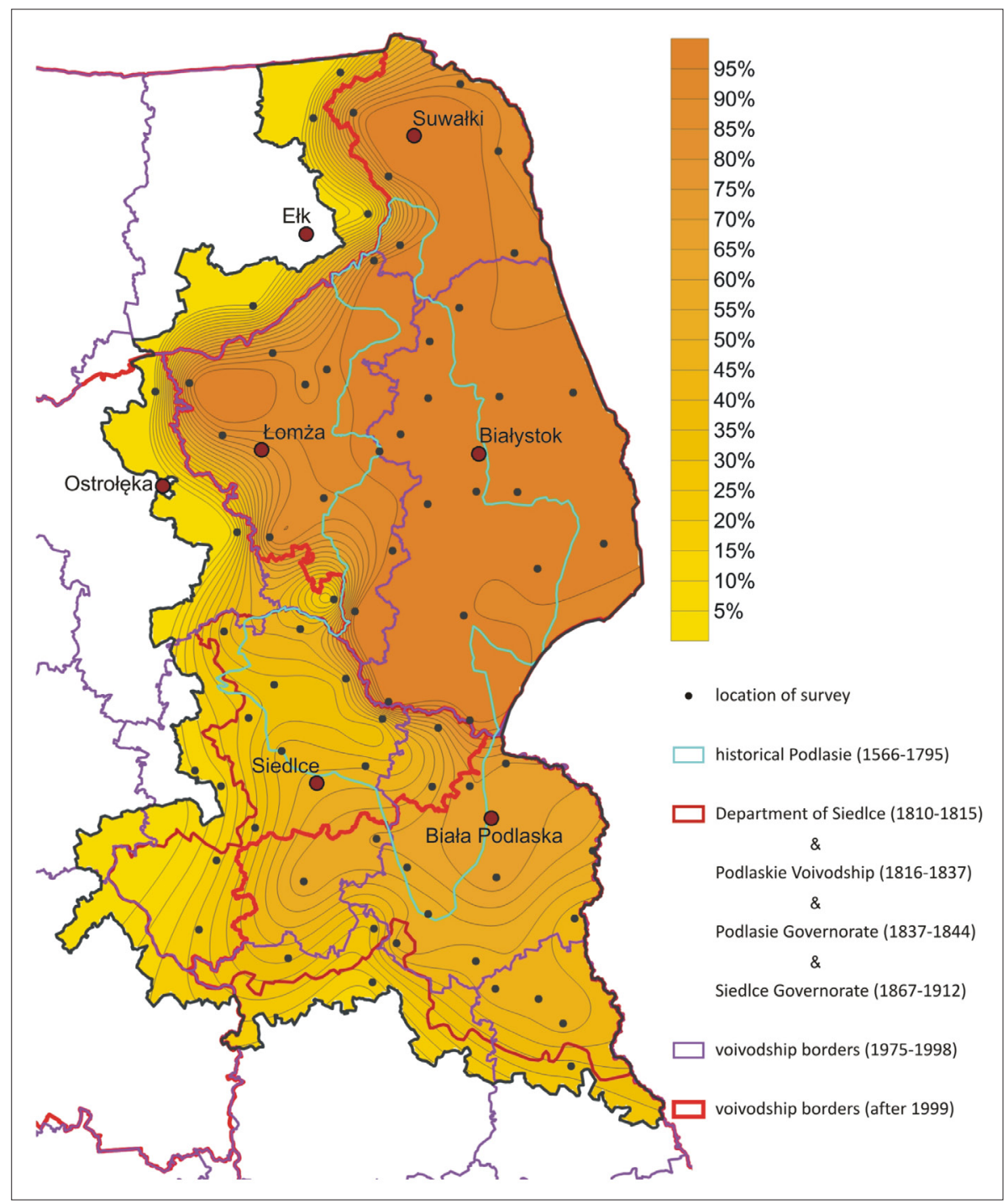

Fig. 6: Synthetic indicator of responses to the question: Do you live in Podlasie? (Question A) Source: author's elaboration based on his survey

former Białostockie Voivodship feel the strongest bonds with Podlasie. Those inhabiting part of the Podlaskie Voivodship, which used to belong to Suwalskie Voivodship, exhibit weaker attachment to Podlasie. Belonging to a past administrative region is evident as respondents from former Łomżyńskie and Suwalskie Voivodships were characterised by a considerably higher uncertainty in answering the question Do you live in Podlasie?, than those of Białostockie Voivodship. Moreover, about one third of Bialskopodlaskie Voivodship's (now part of Lubelskie Voivodship) population are convinced to be living in Podlasie (Tab. 1).

The impact of the last administrative reform on the nature and intensity of the regional identity among surveyed inhabitants is confirmed by their relatively low attachment to former voivodships (from 1975-1998) ${ }^{7}$ (Fig. 7). Inhabitants of the Białostockie Voivodship show the lowest attachment to this administrative region. The city of Białystok has not lost its function as a voivodship capital city as a result of the administrative reform, and its importance has de facto increased since 1999. Białystok also fits into the regional identity of the inhabitants of the former Białostockie Voivodship, whose residents at the same time identify themselves most strongly with Podlasie. Restoration of the former voivodship would cause Białystok's decline in rank. Overall, in the remaining research area, respondents' attachment to the former voivodships (19751998) is relatively low. A significantly higher willingness to restore these administrative regions, however, is noticeable among respondents living in communes located near their capitals (Biała Podlaska, Siedlce, Łomża, Suwałki). The increase of the discussed indicator from the peripheries of former voivodships towards their main cities is evident (Fig. 7).

Such interdependence results from greater attachment among inhabitants of adjacent communes to the former voivodship capital in functional and spatial aspects (education, labour market and related commuting, i.e. factors building attachment). A restoration of former voivodships and their capitals would increase the prestige of the capital city of the region lost in the 1999 administrative reform. The stronger attachment to the former Bialskopodlaskie, Łomżyńskie, Siedleckie and Suwalskie Voivodships compared to Białostockie may, to some extent, result from opposition to the name of the present Podlaskie

\footnotetext{
${ }^{7}$ Based on analysing obtained answers to the question: Would you like to restore the former voivodship from the years $1975-1998 ?$
} 


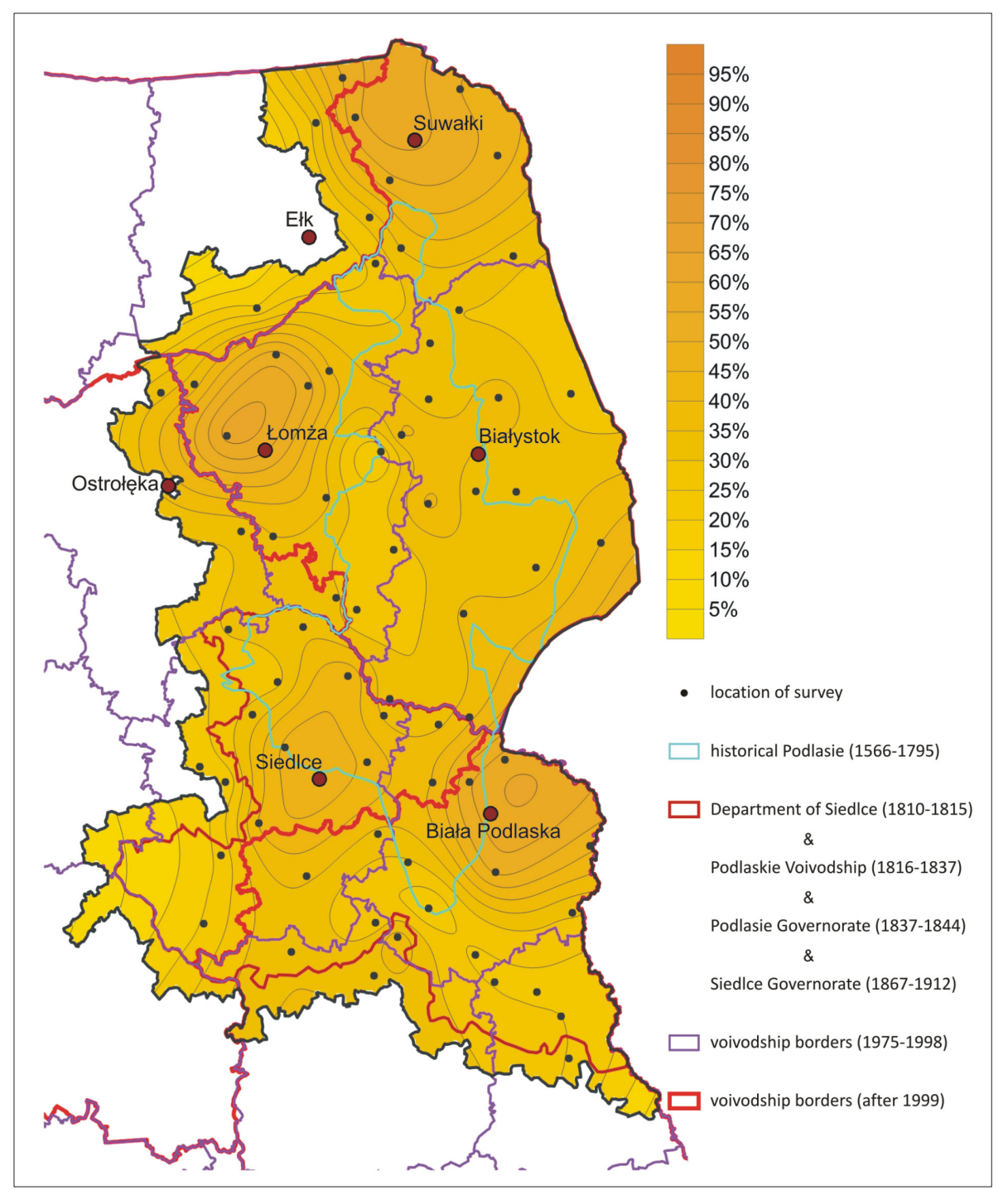

Fig. 7: Synthetic indicator of responses to the question: Would you like to restore the former voivodship from the years 1975-1998? (Question B). Source: author's elaboration based on his survey

Voivodship. Inhabitants of communes located in the former Łomżyńskie Voivodship, which belonged to the historical Podlasie region, have significantly lower support for its restoration. They identify themselves more strongly with Podlasie than with the Łomża region. In communes located around the town of Łomża the situation is inverse, some of the respondents do not identify themselves with Podlasie nor Podlaskie Voivodship (these communes were not located in the historical Podlasie), and thus are more attached to former voivodship. Higher values of this indicator, however, may result not so much from respondents' identity colliding with the name and territory of the new administrative units, but from local patriotism or sentiment for the lost voivodship.

Based on this research, one may state that the borders of contemporary Podlaskie Voivodship have exacted a toll upon perceptions of the historical and administrative region ${ }^{8}$. Respondents living in this administrative region - and even more so in Białostockie Voivodship, being its fragment - to the highest extent identify Podlasie and Podlaskie Voivodship as one area (Tab. 1.) As discussed earlier, these terms function as synonyms - used commonly - not only among the inhabitants of the latter. A similar pattern also applies to other regions, such as the synonymous use of the names Mazowieckie Voivodship and Mazovia, Śląskie Voivodship and Silesia, etc. ${ }^{9}$. The extent of such territorial and semantic perceptions has certainly contributed to confusion when responding to the questionnaire. Synonymous use of the discussed toponyms is reflected in the relatively even intensity of this indicator across the entire study area and inconsiderable (mainly local) spatial polarisation (Fig. 8).

The value of this indicator is lower in the communes which belonged to the historical Podlasie and are currently located in the Lubelskie and Mazowieckie Voivodships (especially in the former Bialskopodlaskie Voivodship, Tab. 1). This is a premise to state that respondents living therein identify themselves with Podlasie and not with Podlaskie Voivodship. They therefore distinguish the different meaning of these terms more clearly than the rest of respondents.

\footnotetext{
${ }^{8}$ Based on analysing obtained answers to the question: Do you consider that Podlaskie Voivodship and Podlasie cover the same area?

${ }^{9}$ In these cases, borders of historical and administrative regions are also incoherent as observed in the scientific community (e.g. Bialasiewicz, 2002; Miszczuk, 2003; Zaborowski, 2013; Nowak, 2018).
} 


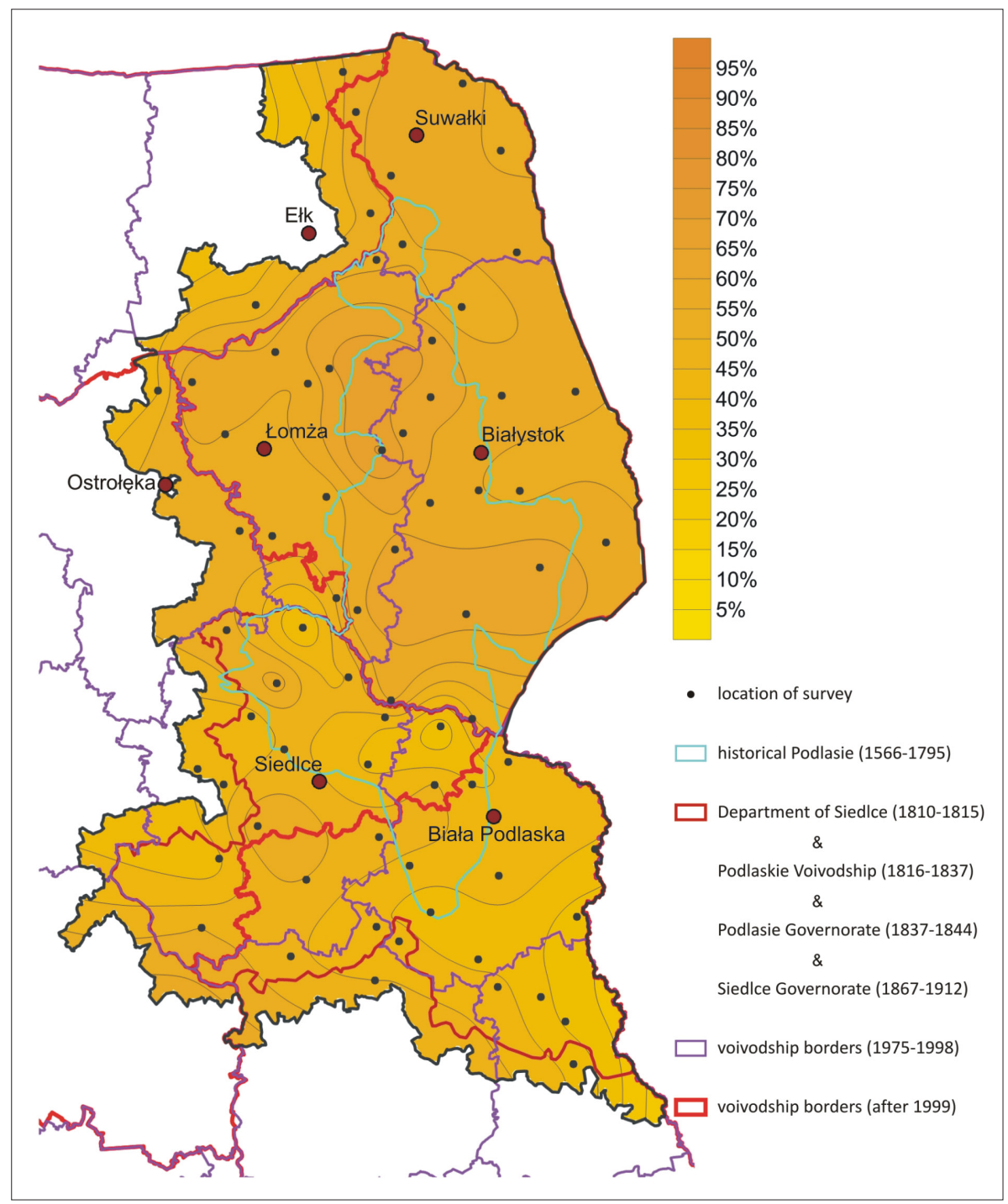

Fig. 8: Synthetic indicator of responses to the question: Do you consider that Podlaskie Voivodship and Podlasie cover the same area? (Question C)

Source: author's elaboration based on his survey

For examining their spatial perception of Podlasie, respondents were asked to outline borders of this region on a schematic map (Fig. 9a). The responses that were obtained seem to confirm prior observations that generally Podlasie is perceived as the Podlaskie Voivodship (Fig. 9b). The highest proportions of indications are within the borders of the latter, and especially the former Białostockie Voivodship. Most above $95 \%$ - respondents perceive the city of Białystok to be located in Podlasie.

Despite a largely convergent spatial "picture" of historical and administrative regions, there are however certain exceptions. A significant share of towns considered to be part of Podlasie is located outside Podlaskie Voivodship. This may be caused by either respondents' knowledge concerning the historical borders of Podlasie or by toponyms of reference towns (Biała Podlaska, Radzyń Podlaski, Sokołów Podlaski) suggesting such regional affiliation. The general perception of Podlasie (Fig. 9) to a great extent correlates with the cartographic presentation of respondents' answer to the question: Do you live in Podlasie? (Fig. 6). This might suggest that the surveyed population living in historical Podlasie more willingly outlines the region's borders outside the Podlaskie Voivodship, and consider themselves to be living in Podlasie understood as a cultural and not administrative region.
The research conducted in this project has demonstrated that Podlasie is perceived differently depending upon the location in which the survey was taken. The most pronounced variations in comparison to the overall perception of the examined region have been identified between the spatial comprehension of Podlasie among inhabitants of the current Podlaskie Voivodship and former Governorate of Podlasie/ Siedlce (Fig. 10). These communities are separated by the border at the Bug River.

The inhabitants of Podlaskie Voivodship tend to associate its borders with Podlasie to a considerably greater extent than all surveyed respondents. The most pronounced differences in this regard concern northern and western parts of the Podlaskie Voivodship, which in historical terms have never belonged to Podlasie. On the other hand, surveyed respondents living in the former Governorate of Podlasie/ Siedlce, exhibit opposite spatial dependency compared to the overall "picture" of Podlasie. Figures 10 a) and b) are thus "negatives" of each other. Respondents living in the former Governorate of Podlasie/Siedlce to a significantly lesser extent associate Podlasie with Podlaskie Voivodship, tending to emphasise its borders south of the Bug river, being at the same time their place of residence. This might serve as a premise that they may also feel attached to Podlasie, 


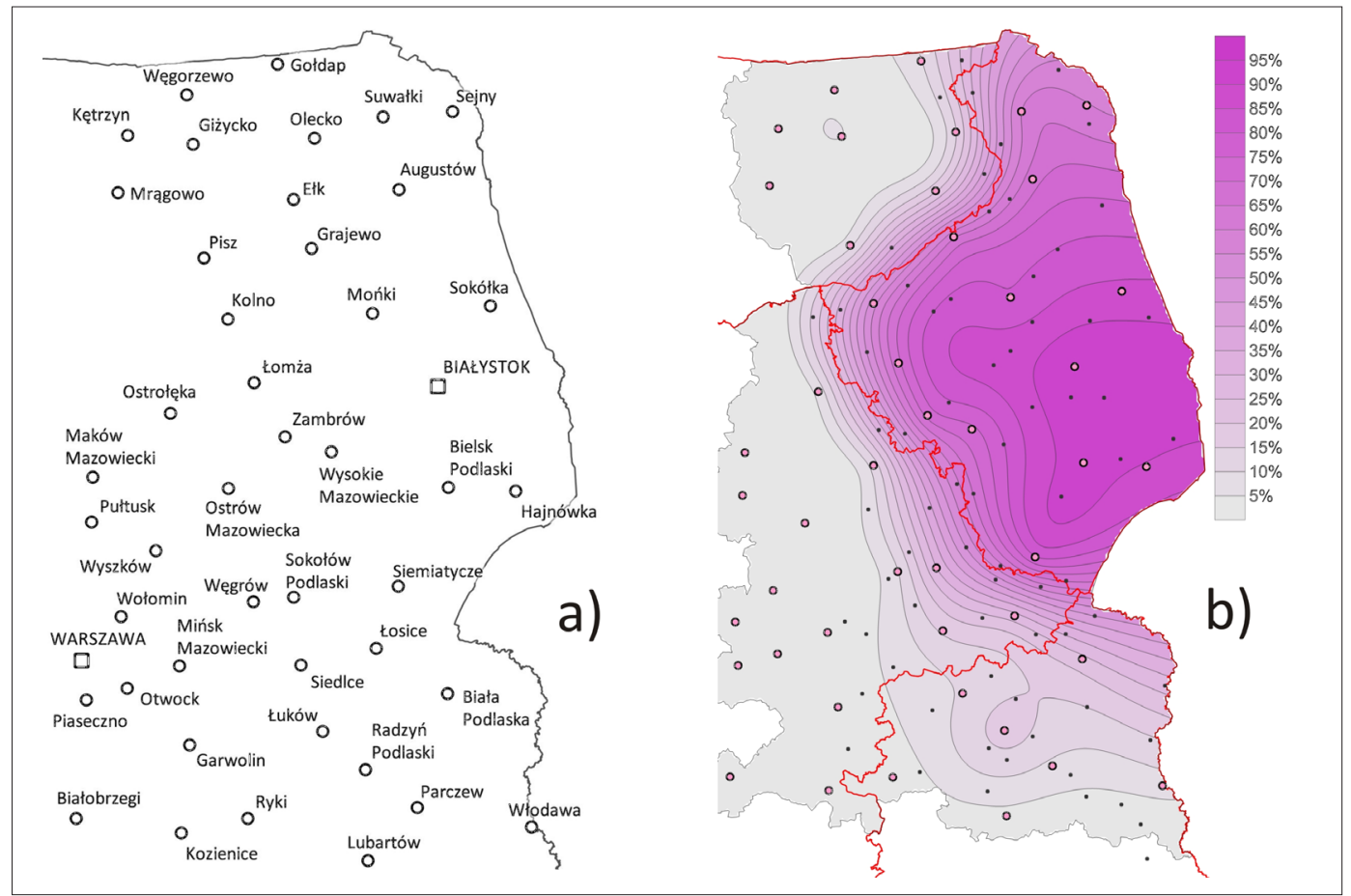

Fig. 9: a) Schematic map of north-eastern Poland; (b) Synthetic perception of Podlasie by all respondents: The percentage of towns included in the outlined region used for the question "Where do you think Podlasie is located? Please outline the borders of Podlasie on a schematic map”. Source: author's elaboration based on his survey

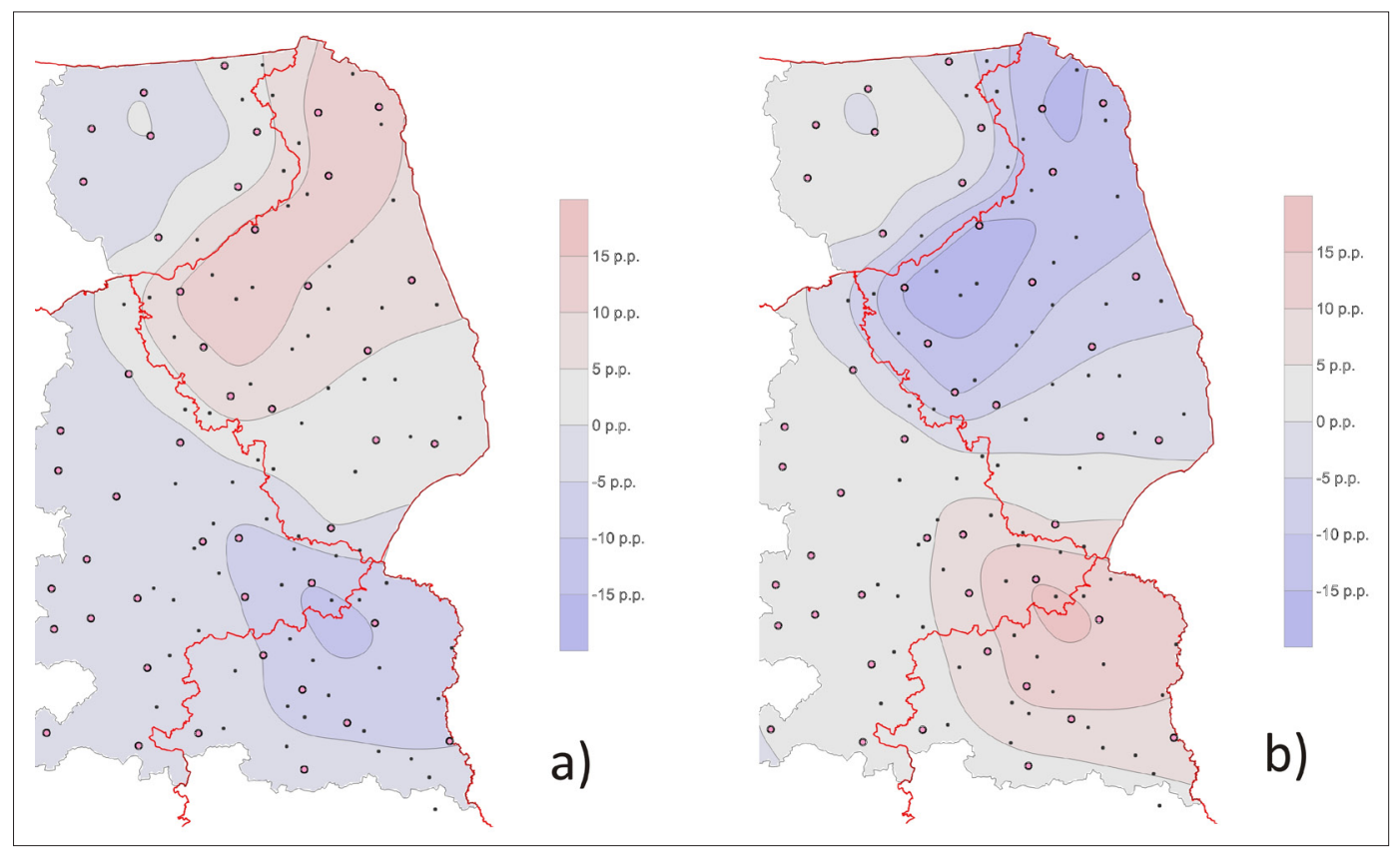

Fig. 10: Differences in the perception of Podlasie by a) inhabitants of the Podlaskie Voivodship (left) and b) inhabitants of former Governorate of Podlasie/Siedlce (right), in relation to all surveyed respondents (\%)

Source: author's elaboration based on his survey

however - not perceived as a current administrative region but a historical and cultural region delimited by relict borders. As already shown (Fig. 8) surveyed inhabitants of the former Governorate of Podlasie/Siedlce - to the least extent - consider that Podlaskie Voivodship and Podlasie cover the same area (see responses to this question for Bialskopodlaskie and Siedleckie Voivodships in Tab. 1) This might also express their opposition towards perceiving Podlasie solely in administrative terms as Podlaskie Voivodship.
The perceived area of Podlasie is relatively broad as the majority of respondents associate its territory with administrative borders and some with a historical region. As observed by Melnychuk and Gnatiuk (2018), the name of the region is a somewhat conservative backbone in reconfiguring perceived regions over time. Naming a clearly delimited region imposes specific spatial perceptions with attributed semantics. Research conducted by Semian (2012) on perceptions of the area of the Bohemian Paradise (Český ráj) corresponds to this statement. In that study, there is no 
institutionalised region named that way. As a consequence, the majority of respondents included a relatively small area referring to the Bohemian Paradise on their mental maps. Concurrently, this was the prevailing definition of Bohemian Paradise in the discourse corresponding to a protected landscape area - officially named Bohemian Paradise. Synonymous understanding of the names attributed to administrative and historical regions in the case of Podlasie results in a significant share of respondents who identify Podlasie with the combined area of these two territories.

\section{Conclusions}

This study has confirmed the complexity of people-place interrelations. Statistical analysis evidenced that factors responsible for shaping attachment to the examined spatial tiers are not obvious. The fact of being born in a given place or having a certain educational level are not decisive for relations with inhabited territory. A declared nationality and religion, as well as age and period of residence, are shown to be most significant. Gender and occupation are secondary factors determining attachment.

The hierarchy of respondents' bonds with a given area proved to be relatively predictable. One may state that there is a clearly stronger identification with the national and local tiers in comparison to the regional rank. A lower attachment to region can be considered a result of unstable administrative borders in Poland, through the prism of which inhabitants primarily perceive the territory of Podlasie. This inquiry has given evidence of a relatively strong attachment related to the informal (sub)region of Eastern Poland, which among certain communities surpassed bonds with administrative units, both current and historical. Hence, governance and the administrative approach towards space are not the only factors determining relations between people and places.

An identification of the respondents with Podlasie in the Podlaskie Voivodship is evident, though not confined to its borders. The greatest attachment in this respect is observed among residents of the former Białostockie Voivodship (1975-1998). Historical conditions exert an observable impact upon relations to Podlasie, and its spatial perception as relict regions show such attachments. One may state that regional collective memory to some extent resists changing administrative borders. Yet, the examined territorial identity is shared with generally stronger bonds with current administrative regions. These findings correspond to research results concerning Podolia, Ukraine (Melnychuk and Gnatiuk, 2018) that the majority of a regions' inhabitants have a "hybrid" territorial identity, combining old and new qualities. The current administrative divides are decisive for perceptions of Podlasie and attachment to this region. Such regional identity is not uniform, however, and especially outside Podlaskie Voivodship it comprises a variety of regional and sub-regional attachments. Despite the specificity of the research area, in consciousness of such a varied community, perception of the region - primarily as an administrative unit - is commonly shared.

The institutionalisation of a region as specified by Paasi (1986, 1991, 1996), concerning the imaginaries and identities of a region's population along with territorial, symbolic, institutional and organisational issues, may contribute to a collective identification process. It the case of this research area, such a process has begun by means of the administrative reform in 1999. Podlasie presently operates in semantic and geographical terms as an administrative region. Statistical analysis has shown that inhabiting Podlaskie Voivodship strengthens such relations. The historical factor is crucial in this respect, however, as living in the former Białostockie Voivodship determines attachment to Podlasie even more explicitly. One now encounters a similar process as that in the $19^{\text {th }}$ century when the perception of Podlasie was altered due to establishing administrative regions south of the Bug River. Naming the region with a derivate of the word Podlasie fostered establishing specific perceptions and semantics of the territory called Podlasie. By imposing borders of a new region in 1999, such a mechanism has covered northern and western areas of current Podlaskie Voivodship, which historically were not related to Podlasie.

This goes in line with the observation that 'region' is primarily a social construct (Paasi, 2011; Van Langenhove, 2013). Therefore, regional identity should not be understood as a fixed phenomenon, but rather as a continuous process in which space, time, community activity and memory are its fundamental elements (Raffestin, 2003). Apart from these components, a crucial factor contributing to enhanced altering regional identity and a region's perception is the semantics. In social consciousness, not only the names Podlasie and Podlaskie Voivodship became synonyms, but also their symbolism, cultural heritage and borders are to a great extent perceived univocally. But the identity of a historical region has persisted. As stated by Antonsich (2010), if an administrative region may exist in the absence of regional identity, then possibly regional identity can exist in the absence of regional institutions. In the case of Podlasie, a hybrid regional identity has been undoubtedly established pertaining to both administrative and historical regions. Such a combined identity takes diverse proportions, even though attachment to the contemporary voivodship generally prevails.

The semantics of administrative and historical toponyms is crucial in building both the "identity of a region" in public discourse, and the "regional identity" of inhabitants. In such a way, some form of a region's institutionalisation takes place, in which historical borders lose their importance in favour of administrative divides. It is therefore evident that "everyday acts of naming constitute the first step of regional becoming" (Bialasiewicz, 2002, p. 119). This mechanism was recognised by Paasi (1996, p. 35) who stated that naming the region "brings together its historical development, its important events, episodes and memories and joins personal histories of its inhabitants to this collective heritage". Naming the area Podlaskie Voivodship has transferred much of the "old" identity of the region to establish a new regional identity to be found within administrative borders. Attachment to the present region, however, cannot be equated with bonds to the historical Podlasie, built for hundreds of years. Presently, the identity of the region, regional identity and the associated regional history is selective, generalised and reinterpreted for the sake of various - mainly economic goals (Semian and Nováček, 2017). Attachment to historical regions still persists in the collective memory of the surveyed population. This has been shown in the research area outside the Podlaskie Voivodship, but located in historical Podlasie, thus beyond the impact of administrative or economic factors. Such bonds are evident among the oldest age group $(60+)$ and thus are likely to be displaced over time by attachment to the administrative region, now dominant among the younger population.

With reference to research on the impact of institutionalising new regions (Zimmerbauer et al., 2012) and especially relevant to the issue being examined, amalgamations of regions and its impact on regional 
identity (Zimmerbauer and Paasi, 2013), one may draw a general conclusion, that this research has not provided evidence whether regional identity has fostered establishing the new region of Podlasie. In turn, the study has demonstrated a reverse process: the institutionalisation of an administrative region by amalgamation of smaller units has fostered establishing "regional identity", attributed to Podlasie.

\section{References:}

ANTONSICH, M. (2010): Exploring the correspondence between regional forms of governance and regional identity: The case of Western Europe. European Urban and Regional Studies, 17(3): 261-276.

BARTŁOMIUK, A. (2003): Obszary wiejskie województwa podlaskiego w perspektywie integracji z UE. In: Bocian, A. F. [ed.]: Podlasie granicą Europy (pp. 115-130). Białystok, Wydawnictwo Uniwersytetu w Białymstoku.

BAŃSKI, J., KOWALSKI, M., MAZUR, M. (2012): Spatial differences in voting behaviour among inhabitants of rural Poland, as exemplified by parliamentary elections in the period 1993-2007. Geograficky Casopis, 64(2): 91-109.

BARWIŃSKI, M. (2004): Podlasie jako pogranicze narodowościowo-wyznaniowe. Łódź, Wydawnictwo Uniwersytetu Łódzkiego.

BARWIŃSKI, M. (2014): Podlasie jako region pogranicza, Studia z Geografii Politycznej i Historycznej, 3: 281-306.

BECKLEY, T. S. (2003): The relative importance of sociocultural and ecological factors in attachment to place, General Technical Report PNW-GTR-566, In: Kruger, L. E. [ed.]: Understanding community - forest relations (pp. 105-126). Portland, Oregon: U.S. Department of Agriculture, Forest Service. Pacific Northwest Research Station.

BIALASIEWICZ, L. (2002). Upper Silesia: Rebirth of a regional identity in Poland. Regional \& Federal Studies, 12(2): 111-132.

BIALASIEWICZ, L. (2003). Another Europe: remembering Habsburg Galicja. Cultural Geographies, 10(1): 21-44.

BOCIAN, A. F. [ed.] (2003a): Podlasie granica Europy. Białystok, Wydawnictwo Uniwersytetu w Białymstoku.

BOCIAN, A. F. (2003b): Podlasie - nowe możliwości i szanse. In: Bocian A. F. [ed.], Podlasie granicą Europy (pp. 18-31). Białystok, Wydawnictwo Uniwersytetu w Białymstoku.

BOCIAN, A. F. [ed.] (2004): Podlasie - wizja rozwoju. Białystok, Fundacja Promocji Rozwoju Podlasia.

BOCIAN, A. F. [ed.] (2005): Podlasie a procesy integracji. Białystok, Wydawnictwo Uniwersytetu w Białymstoku.

BOCIAN, A. F. [ed.] (2008): Podlasie - dwie dekady transformacji. Białystok, Wydawnictwo Uniwersytetu w Białymstoku.

BOCIAN, A. F., PERŁO, D., PIĄTKOWSKI, P. [eds.] (2016): Podlasie - wizje przemian i rozwoju. Białystok, Fundacja Promocji Rozwoju Podlasia.

BOKSZAŃSKI, Z. (2005): Tożsamości zbiorowe. Warszawa, Wydawnictwo Naukowe PWN.

BUTTIMER, A. (1980): Home, reach, and the sense of place. In: Buttimer, A., Seamon, D. [eds.]: The human experience of space and place (pp. 166-187). New York, St. Martin's Press.
CHOJNICKI, Z. (1996): Region w ujęciu geograficznosystemowym. In: Czyż, T. [ed.]: Podstawy regionalizacji geograficznej (pp. 7-43). Poznan, Bogucki Wydawnictwo Naukowe.

CZEMIEL-GRZYBOWSKA, W. (2006): Wpływ funduszy przedakcesyjnych na funkcjonowanie małych i średnich przedsiębiorstw w regionie podlaskim, Rozprawy Naukowe Seria I. Białystok, Wyższa Szkoła Finansów i Zarzadzania w Białymstoku.

DZIEKANOWSKA， M. (2015): Poczucie tożsamości regionalnej mieszkańców Lubelszczyzny. Lublin, Wydawnictwo Uniwersytetu Marii Curie-Skłodowskiej.

ERIKSON, E. (1974): Identity. Youth and Crisis. London, Faber \& Faber.

FERENC, M. (2016): Osadnictwo. In: Bański, J. [ed.]: Atlas obszarów wiejskich w Polsce (pp. 45-52). Warszawa, IGiPZ PAN

FISHWICK, L., VINING, J. (1992): Toward a phenomenology of recreation place. Journal of Environmental Psychology, 12: 57-63.

GALASIŃSKA, A. (2003): Temporal shifts in photo-elicited narratives in a Polish border town. Narrative Inquiry, 13: 393-411.

GEISS, I. (1996): Lud, terytorium, naród, państwo. In: Wojciechowski, M., Schattkowsky, R. [eds.] Regiony pograniczne Europy Środkowo-Wschodniej w XVI-XX wieku. Społeczeństwo - gospodarka - polityka (pp. 2349). Torun, UMK.

GIDDENS, A. (1985): The Nation-state and Violence. Cambridge, Polity Press.

GLOGER, Z. (1918): Opis historyczny Podlasia i ziemi Chełmskiej. In: W obronie ziemi. Z przedmową Zygmunta Chrzanowskiego. Z dwiema mapami, (pp. 7-18). Warszawa, Skład Główny w Biurze Pracy Społecznej.

GUSTAFSON, P. (2009): Mobility and territorial belonging. Environment and Behavior, 41: 490-508.

HARTSHORNE, R. (1936): Suggestions on the terminology of political boundaries. Annals of the Association of American Geographers, 22: 48-49.

HRYNIEWICZ, J., POTRYKOWSKA, A. [eds.] (2017): Sytuacja demograficzna Podlasiajako wyzwanie dla polityki społecznej i gospodarczej. Warszawa, Rządowa Rada Ludnościowa.

HUNTINGTON, S. (1998): Zderzenie cywilizacji i nowy kształt ładu światowego. Warszawa Muza S. A

JABŁONOWSKI, A. (1910): Podlasie, cz. 3. In: Polska XVI w. pod względem geograficzno-statystycznym, VI. (pp. 257-258). Warszawa, Gebethner i Wolff.

JANC, K., CZAPIEWSKI, K., WÓJCIK, M. (2019): In the starting blocks for smart agriculture: The Internet as a source of knowledge in transitional agriculture. NJAS Wageningen Journal of Life Sciences, 90-91: 1-12.

JORDAN, T. G. (1978): Perceptual regions in Texas. Geographical Review, 68(3): 293-307.

KELLY, G., HOSKING, K. (2008): Nonpermanent Residents, Place Attachment and "Sea Change" communities. Environment and Behavior, 40: 575-594.

KNIGHT, D. B. (1982): Identity and Territory: Geographical Perspectives on Nationalism and Regionalism. Annals of the Association of American Geographers, 72(4): 514-531. 
KOŁODZIEJSKI, J. (1991): Podział terytorialny (administracyjny) kraju jako problem organizacji przestrzennej społeczeństwa, gospodarki i państwa. Biuletyn Komitetu Przestrzennego Zagospodarowania Kraju PAN, 156: 7-34.

KOMORNICKI, T. (2010): Rola wymiany towarowej ze wschodnimi sąsiadami Polski w gospodarce lokalnej. Prace Komisji Geografii Przemysłu, 15: 105-116.

KOMORNICKI, T., ROSIK, P., ŚLESZYŃSKI, P., SOLON, J., WIŚNIEWSKI, R., STĘPNIAK, M., CZAPIEWSKI, K., GOLISZEK, S. (2013): Impact of the construction of motorways and expressways on socio-economic and territorial development of Poland. Warszawa, Ministry of Infrastructure and Development.

KORPELA, K. M. (1989): Place identity as a product of self-regulation. Journal of Environmental Psychology, 9: 241-256.

LACZKO, L. S. (2005): National and local attachments in a changing world system: Evidence from an international survey. International Review of Sociology, 15: 517-528.

LEWICKA, M. (2011): Place attachment: How far have we come in the last 40 years? Journal of Environmental Psychology, 31: 207-230.

LOW, S. M. (1992): Symbolic ties that bind. Place attachment in the plaza. In: Altman, I., Low, S. M. [eds.]: Place attachment (pp. 165-185). New York and London, Plenum Press.

LYNCH, K. (1960): The image of the city. Cambridge, M.I.T. Press.

ŁUKOWSKI, W. (2002): Społeczne tworzenie ojczyzn. Studium tożsamości mieszkańców Mazur. Warszawa, Wydawnictwo Naukowe Scholar.

MALICKI, K. (2010): Pamięć zbiorowa jako element tożsamości regionalnej na przykładzie regionu podkarpackiego. In: Rykiel, Z. [ed.]: Tożsamość terytorialna $\mathrm{w}$ różnych skalach przestrzennych (pp. 124-134). Rzeszów, Wydawnictwo Uniwersytetu Rzeszowskiego.

MATYKOWSKI, R. (1996): Rola świadomości regionalnej w kształtowaniu granic regionu poznańskiego. In: Czyż, T. [ed.]: Podstawy regionalizacji geograficznej (pp. 127140). Poznan, Bogucki Wydawnictwo Naukowe.

MATYKOWSKI, R. (2017): Zbiorowości społecznoprzestrzenne i ich związki z terytorium: formy i czynniki regionalizmu w Polsce. Poznan, Bogucki Wydawnictwo Naukowe.

MAZUR, M. (2016): Demografia. In: Bański, J. [ed.]: Atlas obszarów wiejskich w Polsce (pp. 53-70). Warszawa, IGiPZ PAN.

MAZUREK, M. (2010): Język, przestrzeń, pochodzenie. Analiza tożsamości kaszubskiej. Gdansk, Instytut Kaszubski.

MELNYCHUK, A., GNATIUK, O. (2018): Regional identity and the renewal of spatial administrative structures: The case of Podolia, Ukraine. Moravian Geographical Reports, 26(1): 42-54.

MICHALUK, D. (2013): Granice województwa podlaskiego i postrzeganie obszaru Podlasia w latach 1513-2013. In: Podlasie nadbużańskie. 500-lecie województwa podlaskiego (pp. 169-199). Białystok, Muzeum
Rolnictwa im. ks. Krzysztofa Kluka Instytucja Kultury Województwa Podlaskiego, Urząd Marszałkowski Województwa Podlaskiego Departament Kultury i Dziedzictwa Narodowego.

MILGRAM, S. (1970): The experience of living in cities. Science, 167: 1461-1468.

MISZCZUK, A. (2003): Regionalizacja administracyjna III Rzeczpospolitej. Koncepcje teoretyczne a rzeczywistość. Lublin, Wydawnictwo Uniwersytetu Marii CurieSkłodowskiej.

NORBERG-SCHULTZ, C. (1979): Genius loci. Towards a phenomenology of architecture. New York, Rizzoli.

PETROZOLIN-SKOWROŃSKA, B. (1998): Nowa Encyklopedia Powszechna 4. Warszawa, Wydawnictwo Naukowe PWN.

NOWAK, K. (2018): Wpływ przebiegu granic województw na tożsamość regionalną oraz postrzeganie regionów Małopolski i Śląska. Studia Regionalne i Lokalne, 1(71): $62-81$.

OTREMBA, T. (1997): Wyżyna Polska. Gdansk, Regnum.

PALMOWSKI, T. [ed.] (2007): Pogranicze polsko-rosyjskie. Problemy współpracy transgranicznej z Obwodem Kaliningradzkim. Gdynie, Wydawnictwo Bernardinum.

PAASI, A. (1986): The Institutionalization of Regions: A Theoretical Framework for Understanding the Emergence of Regions and the Constitution of Regional Identity. Fennia, 164(1): 105-146.

PAASI, A. (1991): Deconstructing regions: notes on the scales of human life. Environment and Planning A, 23: $239-256$.

PAASI, A. (1996): Territories, Boundaries and Consciousness: The Changing Geographies of the Finnish-Russian Border. London, John Wiley.

PAASI, A. (2002): Place and Region. Regional Worlds and Words. Progress in Human Geography, 26(6): 802-811.

PAASI, A. (2003): Region and place: regional identity in question. Progress in Human Geography, 27: 475-485.

PAASI, A. (2011): The region, identity, and power. Procedia Social and Behavioural Sciences, 14: 9-16.

PÁSZTO, V., MACKU゚, K., BURIAN, J., PÁNEK, J., TUČEK, P. (2019): Capturing cross-border continuity: The case of the Czech-Polish borderland. Moravian Geographical Reports, 27(2): 122-138.

PATTERSON, M. E., WILLIAMS, D. R. (2005): Maintaining research traditions on place: Diversity of thought and scientific progress. Journal of Environmental Psychology, 25: 361-380.

PEZZINI, M. (2000): Territorial Governance: Main issues and Trends in OECD countries. In: Territorial Development Policies and Issues (pp. 197-207). Paris, OECD.

PISKOZUB, A. (1987): Dziedzictwo polskiej przestrzeni: geograficzno-historyczne podstawy struktur przestrzennych ziem polskich. Wrocław, Zakład Narodowy im. Ossolińskich.

PLAWGO, B., SADOWSKA-SNARSKA, C. (2004): Rynek pracy w regionie podlaskim - stan i perspektywy. Białystok, Wydawnictwo Wyższej Szkoły ekonomicznej w Białymstoku.

POHL, J. (2004): Regional Identity. In: Smelser, N. J., Baltes, P. B. [eds.]: International Encyclopedia of the 
Social and Behavioral Sciences (pp. 12917-12922). Amsterdam, Elsevier.

POLLICE, F. (2003): The role of territorial identity in local development processes. In: Proceedings of the Conference - The Cultural Turn in Geography, Landscape Construction and Cultural Identity (pp. 107117). Trieste, University of Trieste.

POWESKA, H. (2011): Struktura towarowa handlu przygranicznego na pograniczu polsko-ukraińskim. Roczniki Naukowe Stowarzyszenia Ekonomistów Rolnictwa i Agrobiznesu, 13(2): 371-376.

PRAWELSKA-SKRZYPEK， G. (1996): Świadomość regionalna $\mathrm{w}$ Małopolsce - studium empiryczne. In: Prawelska-Skrzypek, G. [ed.]: Małopolska regionalna wspólnota interesów (pp. 41-59). Nowy Sącz, Wyższa Szkoła Biznesu.

PRETTY, G. H., CHIPUER, H. M., BRAMSTON, P. (2003): Sense of place amongst adolescents and adults in two rural Australian towns: The discriminating features of place attachment, sense of community and place dependence in relation to place identity. Journal of Environmental Psychology, 23: 273-287.

PRONIEWSKI, M., NIEDŹWIECKI, A. (2003): Efekty restrukturyzacyjne wspólnego rynku jako czynnik rozwoju Podlasia. In: Bocian, A. F. [ed.]: Podlasie granicą Europy (pp. 72-80). Białystok, Wydawnictwo Uniwersytetu w Białymstoku.

RAFFESTIN, C. (2003): Immagini e identitŕ territoriali, In: Dematteis, G., Ferlaino, F. [eds.]: Il Mondo e i Luoghi: Geografie dell'identitŕ e del cambiamento (pp. 3-11). Piemonte, IRES.

RAK, G. (2013): Percepcja przestrzeni regionalnej (Dissertation thesis). Opole, Politechnika Opolska, Wydział Wychowania Fizycznego i Fizjoterapii, Instytut Turystyki i Rekreacji, Katedra Turystyki i Promocji Zdrowia.

RELPH, E. (1976): Place and placelessness. London, Pion Limited.

RYKIEL, Z. (1985): Badania świadomości regionalnej przykład regionu katowickiego. Przegląd Geograficzny, 57(1-2): 37-58.

RYKIEL, Z. (1999): Przemiany struktury społecznoprzestrzennej miasta polskiego a świadomość terytorialna jego mieszkańców. Prace Geograficzne, 170. Warszawa, Instytut Geografii i Przestrzennego Zagospodarowania PAN.

RYKIEL, Z. (2010): Tożsamość terytorialna jako uczestnictwo w kulturze. In: Rykiel, Z. [ed.]: Tożsamość terytorialna $\mathrm{w}$ różnych skalach przestrzennych (pp. 17-29). Rzesów, Wydawnictwo Uniwersytetu Rzeszowskiego.

RYKIEL, Z. (2009): Podkarpacie jako region - podstawy teoretyczne. In: Tuziak, A., Tuziak, B. [eds.]: Regionalny wymiar procesów transformacyjnych (pp. 13-28). Warszawa, Scholar.

RYKIEL, Z. (2016): Tożsamość terytorialna, nacjonalizm i kreacja tożsamości lokalnej. In: Wójcicka, M. Dziekanowska, M. [eds.]: Współczesne kreacje tożsamości społeczno-kulturowych (pp. 9-20). Lublin, Uniwersytet Marii Curie-Skłodowskiej.
SADOWSKI, A. (1997): Mieszkańcy północno-wschodniej Polski. Skład wyznaniowy i naro-dowościowy. In: Kurcz, Z. [ed.]: Mniejszości narodowe w Polsce (pp. 7-42). Wroclaw, University of Wroclaw.

SCHATTKOWSKY, R. (1996): Region między Wschodem a Zachodem. Regionalizacja i władza w Europie ŚrodkowoWschodniej. In: Wojciechowski, M., Schattkowsky, R. [eds.]: Regiony pograniczne Europy Środkowo-Wschodniej w XVI-XX wieku (pp. 7-22). Torún, Społeczeństwogospodarka- polityka, Uniwersytet Mikołaja Kopernika.

SCHMIDT, J. (1997): Stereotyp i granica. Pogranicze zaborów w mentalności współczesnych Wielkopolan. Międzychód, Wydawnictwo "ECO".

SCOTT, J. W. (2018): Border politics in Central Europe: Hungary and the role of national scale and nationbuilding. Geographia Polonica, 91(1): 17-32.

SEMIAN, M. (2012). Searching For The Territorial Shape of a Region in Regional Consciousness: The Český Ráj (Bohemian Paradise), Czech Republic. Moravian Geographical Reports, 20(2): 25-35.

SEMIAN, M., NOVÁČEK, A. (2017): The reinterpretation of histories in identities of newly established regions: The case of Local Action Groups in Czechia. Hungarian Geographical Bulletin, 66(4): 307-319.

SOBCZYŃSKI, M. (1984): Niezmienność dawnych granic politycznych na obszarze Polski. Acta Universitatis Lodziensis, Folia Geographica, 3: 119-137.

SOLARZ, M. (2014): Trwałość granic politycznych państwa polskiego w latach 1569/1667-2014. Prace i Studia Geograficzne, 54: 125-138.

STEDMAN, R. C. (2006): Understanding place attachment among second home owners. The American Behavioral Scientist, 50: 187-205.

SZCZEPKOWSKI, J. (1991): Projekt podziału administracyjnego Polski. In: Koncepcje regionalnej organizacji kraju. Biuletyn Komitetu Przestrzennego Zagospodarowania Kraju PAN, 156: 117-132.

SZYFER, A. (1996): Warmiacy. Poznan, Studium tożsamości, Kantor Wydawniczy SAWW.

ŠERÝ, M. (2014): The Identification of Residents with their Region and the Continuity of Socio-Historical Development. Moravian Geographical Reports, 22(3): 53-64.

TAYLOR, R. B., GOTTFREDSON, S. D., BROWER, S. (1985): Attachment to place: discriminant validity and impacts of disorder and diversity. American Journal of Community Psychology, 13: 525-542.

TUAN, Y.-F. (1974): Space and place: Humanistic perspective. Progress in Geography, 6: 233-246.

TUAN, Y.-F. (1975): Place: An experiential perspective. Geographical Review, 65: 151-165.

TUAN, Y.-F. (1977): Space and place: The perspective of experience. Minnesota. The University of Minnesota Press.

VAN LANGENHOVE, L. (2013). What is a region? Towards a statehood theory of regions. Contemporary Politics, 19(4): 474-490.

VAN PATTEN, S. R., WILLIAMS, D. R. (2008): Problems in place: Using discursive social psychology to investigate the meanings of seasonal homes. Leisure Sciences, 30: 448-464. 
VENERI, P. (2011): Territorial Identity in Italian NUTS3 Regions, Il Capitale Territoriale: scenari qualiquantitativi di superamento della crisi economica e finanziaria per le province italiane. Ancona, Dipartimento di Economia - Universitŕ Politecnica del le Marche.

WEIGEND, G. G. (1950): Effects of boundary changes in the South Tyrol. Geographical Review, 40: 364-375.

WHEBELL, C. F. J. (1973): A model of territorial separatism. Annals of the Association of American Geographers, 5: 295-298.

WIŚNIEWSKI, J. (1977): Osadnictwo wschodniej Białostocczyzny. Acta Baltico-Slavica, 11: 7-80.

ZARYCKI, T. (2018): Etosy regionalne a tożsamość narodowapole gry. In: Szomburg, J., Wandałowski, M. [eds.]: Polskie etosy regionalne i ich znaczenie $\mathrm{z}$ perspektywy ogólnonarodowej. Wolność i Solidarność, 82 (pp. 13-21). Gdansk, Instytut Badań nad Gospodarką Rynkową.
ZIMMERBAUER, K., SUUTARI, T., SAARTENOJA, A. (2012): Resistance to the deinstitutionalization of a region: Borders, identity and activism in a municipality merger. Geoforum, 43(6): 1065-1075.

ZIMMERBAUER, K., PAASI, A. (2013): When old and new regionalism collide: Deinstitutionalization of regions and resistance identity in municipality amalgamations. Journal of Rural Studies, 30: 31-40.

ZABOROWSKI, Ł. (2013): Podział kraju na województwa. Próba obiektywizacji. Warszawa, Wydawnictwo Naukowe Scholar.

ŻÓłTOWSKA, J.E. (2011): Podziały politycznoadministracyjne na ziemi podlaskiej w ciągu tysiąclecia, Roczniki Nauk Społecznych, 39(3): 235-269.

\section{Please cite this article as:}

KONOPSKI, M. (2021): The role of administrative borders in determining regional identity: The case of Podlasie, Poland. Moravian Geographical Reports, 29(1): 53-70. Doi: https://doi.org/10.2478/mgr-2021-0005 